\title{
Human actions were responsible for both initiation and termination of varve preservation in Lake Vesijärvi, southern Finland
}

\author{
Sarianna Salminen (D) - Mira Tammelin • Tom Jilbert • Yu Fukumoto • \\ Saija Saarni
}

Received: 16 September 2020/ Accepted: 25 May 2021/Published online: 28 May 2021

(C) The Author(s) 2021

\begin{abstract}
The influence of lake restoration efforts on lake bottom-water conditions and varve preservation is not well known. We studied varved sediments deposited during the last 80 years along a water-depth transect in the Enonsaari Deep, a deep-water area of the southernmost Enonselkä Basin, Lake Vesijärvi, southern Finland. For the last few decades, the Enonselkä Basin has been subject to ongoing restoration efforts. Varve, elemental, and diatom analyses were undertaken to explore how these actions and other human activities affected varve preservation in the Enonsaari Deep. In contrast to most varved Finnish
\end{abstract}

S. Salminen $(\square) \cdot$ M. Tammelin $\cdot$ S. Saarni

Lake and Marine Sediment Research Group, Department

of Geography and Geology, University of Turku,

Akatemiankatu 1, Turku, Finland

e-mail: sarsalm@utu.fi

M. Tammelin

e-mail: mira.tammelin@utu.fi

S. Saarni

e-mail: saija.saarni@utu.fi

M. Tammelin

Freshwater Centre, Finnish Environment Institute,

Latokartanonkaari 11, Helsinki, Finland

T. Jilbert

Ecosystems and Environment Research Program, Aquatic Biogeochemistry Research Unit, Faculty of Biological and Environmental Sciences, University of Helsinki,

Viikinkaari 1, Helsinki, Finland

e-mail: tom.jilbert@helsinki.fi lakes, whose water columns have a natural tendency to stratify, and possess varve records that span thousands of years, varve formation and preservation in Lake Vesijärvi was triggered by relatively recent anthropogenic stressors. The multi-core varve analysis revealed that sediment in the Enonsaari Deep was initially non-varved, but became fully varved in the late 1930s, a time of increasing anthropogenic influence on the lake. The largest spatial extent of varves occurred in the 1970s, which was followed by a period of less distinguishable varves, which coincided with diversion of sewage from the lake. Varve preservation

\author{
T. Jilbert \\ Lake Vesijärvi Foundation, Askonkatu 9C, Lahti, Finland \\ Y. Fukumoto \\ Department of Geosciences, Faculty of Science, Osaka \\ City University, Osaka, Japan \\ e-mail: misudotomakudo@yahoo.co.jp \\ S. Saarni \\ Ecosystems and Environment Research Programme, \\ University of Helsinki, Helsinki, Finland
}


weakened during subsequent decades and was terminated completely by lake aeration in the 2010 s. Despite improvements in water quality, hypolimnetic oxygen depletion and varve preservation persisted beyond the reduction in sewage loading, initial aeration, and biomanipulation. These restoration efforts, however, along with other human actions such as harbor construction and dredging, did influence varve characteristics. Varves were also influenced by diatom responses to anthropogenic forcing, because diatoms form a substantial part of the varve structure. Of all the restoration efforts, a second episode of aeration seems to have had the single most dramatic impact on profundal conditions in the basin, resulting in replacement of a sediment accumulation zone by a transport or erosional zone in the Enonsaari Deep. We conclude that human activities in a lake and its catchment can alter lake hypolimnetic conditions, leading to shifts in lake bottom dynamics and changes in varve preservation.

Keywords Varve preservation - Hypoxia . Eutrophication - Lake restoration - Lake aeration · Diatoms

\section{Introduction}

Excess nutrient inputs to lakes, triggered by human actions (cultural eutrophication), have become a challenge worldwide, causing algal blooms and other changes in lake ecosystems that can compromise water quality (Smith 1998; Diaz 2001; Baulch et al. 2005; Jenny et al. 2016a, 2016b). Cultural eutrophication is typically a consequence of nutrient loads from sewage, industry, agriculture, and construction (Smol 2009). Consequent excessive aquatic primary production and increased degradation of biogenic matter result in enhanced oxygen consumption (Smol 2009; Müller et al. 2012; Friedrich et al. 2014). This can give rise to hypolimnetic hypoxia, i.e. dissolved oxygen concentrations $\leq 2 \mathrm{mg} \mathrm{l}^{-1}$ in deep water.

Lake sediments are sensitive to changes in the water column and catchment, and thus provide crucial archives of environmental information, from which human impact on lake ecosystems can be inferred (Last and Smol 2001; Zolitschka and Enters 2009; Zolitschka et al. 2015). Varved (annually laminated) lake sediments possess records of environmental change, with seasonal resolution. Because varve preservation is dependent on hypoxia, which precludes bioturbation (Zolitschka et al. 2015), the presence of varves in sediment records is an indicator of past hypoxia (Giguet-Covex et al. 2010; Jenny et al. 2013, 2016a, b; Salminen et al. 2019).

The seasonal cycle is the main cause of rhythmic sedimentation, including varve formation, in Finnish lakes (Ojala et al. 2000). This cycle in boreal regions is characterized by fluctuations in snow and ice cover, spring flooding, and the spring-to-autumn growing season. At present, numerous lakes with varved sediments have been identified in Finland (Ojala et al. 2000; Saarni 2017). The varve records in these lakes span thousands of years, from the Early, Middle, or Late Holocene to present. Onset of natural varve preservation is generally dependent on several factors, such as aspects of catchment and lake morphology (e.g. high relative depth) that prevent sediment mixing, erosion, and resuspension (Ojala 2000; Zolitschka 2015). Varve formation and preservation may also be induced in lakes that experience cultural eutrophication (Jenny et al. 2013; Kienel et al. 2013; Hernández-Almeida et al. 2017).

Lake Vesijärvi in southern Finland is an example of a culturally eutrophic lake, in which varve preservation began in the mid-20th century, following rapid growth of the nearby city of Lahti (Liukkonen et al. 1993). Strong anthropogenic control on varve preservation in Lake Vesijärvi makes it an interesting subject for study, compared to other lakes in Finland that possess varved deposits. Furthermore, to improve water quality, the lake has been subjected to a number of restoration efforts since the 1970s, including diversion of urban sewage and storm waters into waste water treatment systems, biomanipulation (mass removal of planktivorous and benthivorous fish, stocking of piscivorous fish), management fishing and aeration (Salonen et al. 2020).

The combined influence of cultural eutrophication and subsequent restoration actions on varve preservation in boreal lakes remains unknown. Research on the topic is important to better understand how varves can be used to infer recent anthropogenic impacts on lakes. The objective of this study was to investigate how human activities, including restoration actions, influenced the onset, development, and termination of varve preservation in the Enonsaari Deep of Lake 
Vesijärvi. We applied analyses of varve microfacies and thickness, elemental composition and diatoms, to explore how anthropogenic forcing influenced varve preservation and characteristics.

\section{Study site}

Lake Vesijärvi (N 61 $01^{\prime} 40^{\prime \prime}$, E $25^{\circ} 35^{\prime} 10^{\prime \prime}$ ) (Fig. 1) is a dimictic lake with several basins, located between the First and the Second Salpausselkä ice-marginal formations, at the southern and northern ends of the lake (Kairesalo and Vakkilainen 2004). The lake surface area is $107.5 \mathrm{~km}^{2}$ and the catchment area is $515 \mathrm{~km}^{2}$. The water retention time is long (6.8 years) and the maximum depth, $42 \mathrm{~m}$, is found in the northernmost Kajaanselkä Basin. Lake Vesijärvi is connected to Lake Päijänne via the Vääksy Canal at the north end of the lake (Fig. 1a) and lake hydrology is also influenced by groundwater seepage (Artimo et al. 2012). Today, loss to groundwater from Lake Vesijärvi occurs mainly to the Salpausselkä formations (Artimo et al. 2012).

Bedrock in the catchment is composed of microcline granite, paragneiss, granodiorite, and quartzite. Land use types in the watershed include forestry, agriculture, urban area, and wetlands (FEI database) (Fig. 1b, c). In addition to the extensive Salpausselkä formations, the surface deposits of the catchment are composed mainly of clay and fine to coarse sand (FEI database) (Fig. 1c). Lake Vesijärvi is located in the boreal climate zone (Ahti et al. 1968). At the Lahti Sopenkorpi weather station, $5.7 \mathrm{~km}$ south of the study site, mean annual precipitation is $653 \mathrm{~mm}$. Mean summer precipitation is $221 \mathrm{~mm}$ and mean winter precipitation is $136 \mathrm{~mm}$ (FMI database). Mean annual, summer, and winter temperatures are 4.4, 15.5, and $-6.0{ }^{\circ} \mathrm{C}$, respectively (FMI database). Ice cover usually forms on Lake Vesijärvi in November/December and thaws in April/early May (HERTTA database). The lake experiences inverse stratification from January to March and direct stratification from mid-June to mid-August. The timing of complete spring overturn varies from early April to late May, and complete autumn overturn from late August to late October.

Since the end of the Middle Ages, i.e. from about the 5 th to 15 th century CE, population in the Lake Vesijärvi catchment increased steadily, culminating in a population explosion in the 20th century (Pekkarinen
2010). Population centralization since the 1960 s caused increased raw sewage loading from cities and was accompanied by construction of transportation infrastructure such as railways and roads (Westerholm 2002). The increase in urban infrastructure and mechanized agriculture in the 20th century caused soil erosion (Pekkarinen 2010) that affected nutrient loading and sedimentation rates in the lake. Furthermore, artificial water level lowering in the 17-19th centuries increased the amount of cultivated area and soil erosion in the Lake Vesijärvi catchment.

Before the foundation of the city of Lahti at the beginning of the 20th century, Lake Vesijärvi was known as a lake with clear water. Greater human influence, e.g. increases in sewage and industrial effluent discharge, during the first decades of the 20th century, led to the first signs of eutrophication in Lake Vesijärvi (Kairesalo and Vakkilainen 2004). By the 1960s and 1970s, Lake Vesijärvi had become one of the most eutrophic large lakes in Finland (Keto 1982; Keto and Sammalkorpi 1988; Liukkonen et al. 1997). The Enonselkä Basin (Fig. 1a), which is located next to the city of Lahti, experienced severe eutrophication (Keto 1982; Keto and Tallberg 2000). Comprehensive restoration actions since the 1970s (Table 1), such as diversion of urban sewage into a waste water treatment facility in 1976, biomanipulation from 1989 to 1993 , and lake aeration from 1979 to 1985 and again since 2010, contributed to some recovery of Lake Vesijärvi (Keto 1982; Keto and Sammalkorpi 1988; Salmi et al. 2014). The lake, however, was still eutrophic in 2018 (Eurofins Environment Testing 2019), with an EU Water Framework Directive water quality grade of "Acceptable." The lake is still on a trajectory to recovery, delayed by internal phosphorus $(\mathrm{P})$ loading from a deep reactive layer in the sediment column that was deposited during the period of greatest past nutrient loading (Jilbert et al. 2020).

\section{Materials and methods}

\section{Sediment coring}

Long sediment cores VJ2, VJ20, VJ22, VJ24, and VJ26 and freeze cores VJ1, VJ19, VJ21, VJ23, and VJ25 were taken from the Enonsaari Deep along a transect of water depths from 23.8 to $32.0 \mathrm{~m}$, in March 2018 (Fig. 1a, Table 2). The long cores, ranging in 


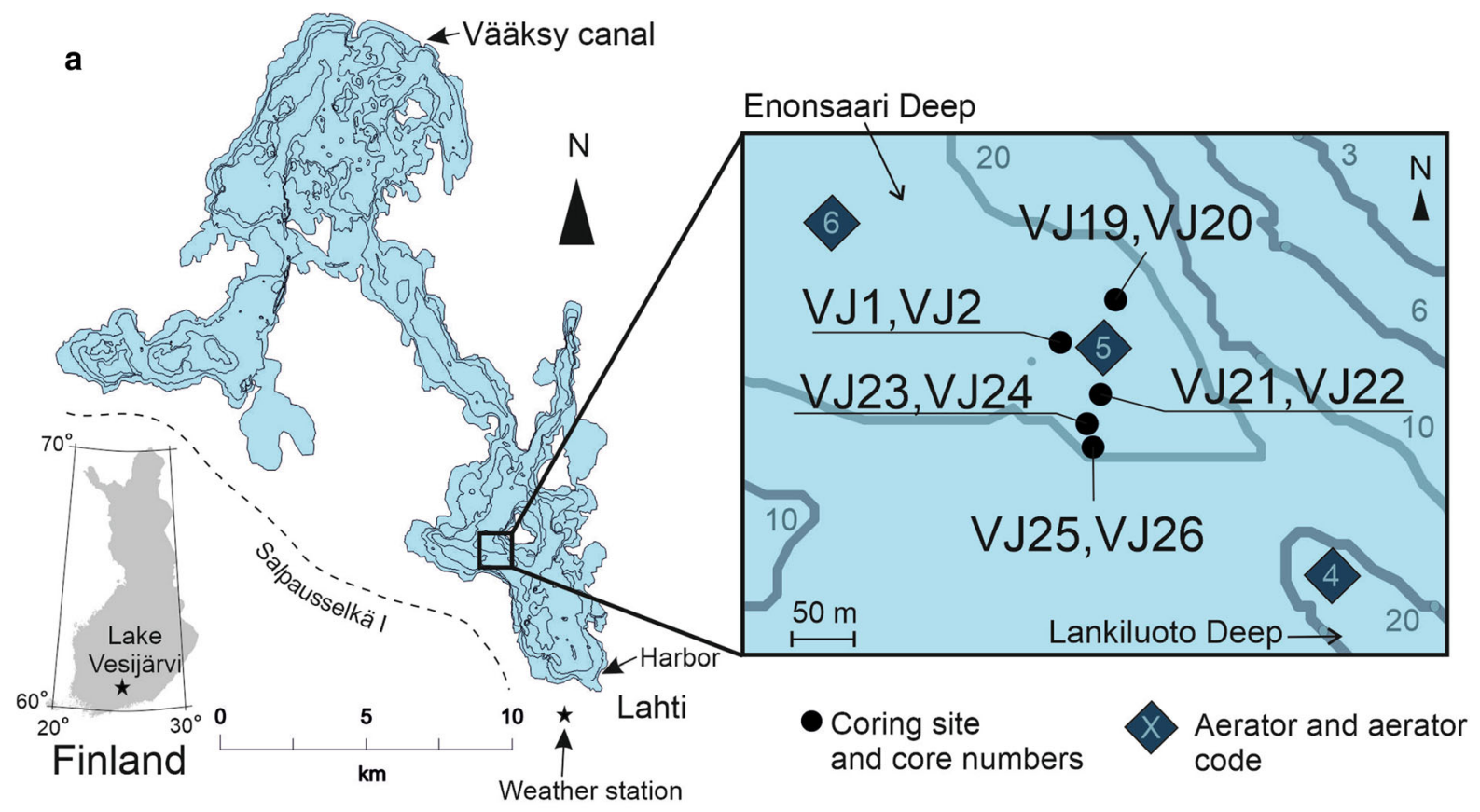

b

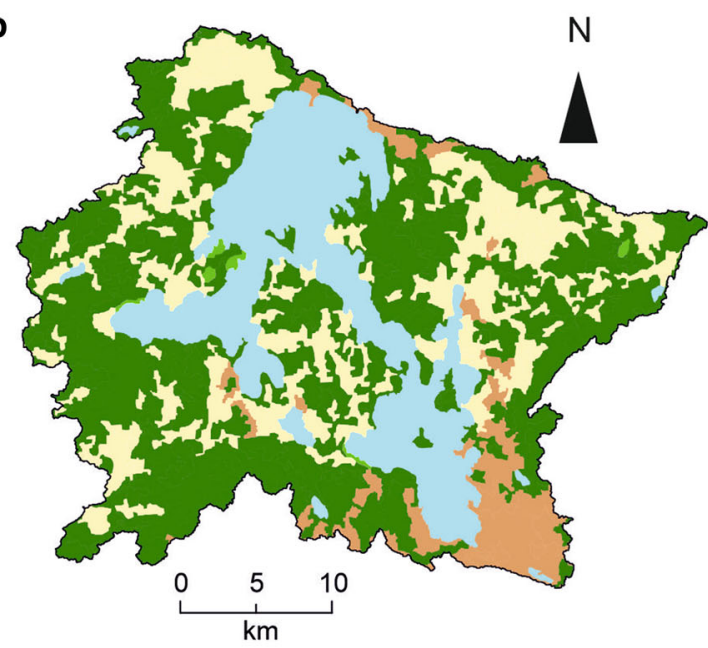

Fig. 1 a Bathymetric map of Lake Vesijärvi with the location of the lake in Finland and the position of the First Salpausselkä icemarginal formation. The inset shows coring locations in the

length from 150 to $167 \mathrm{~cm}$, were taken with a Livingstone-type piston corer. The freeze cores $(\sim 30 \mathrm{~cm}$ long) were taken with an HTH sediment
C
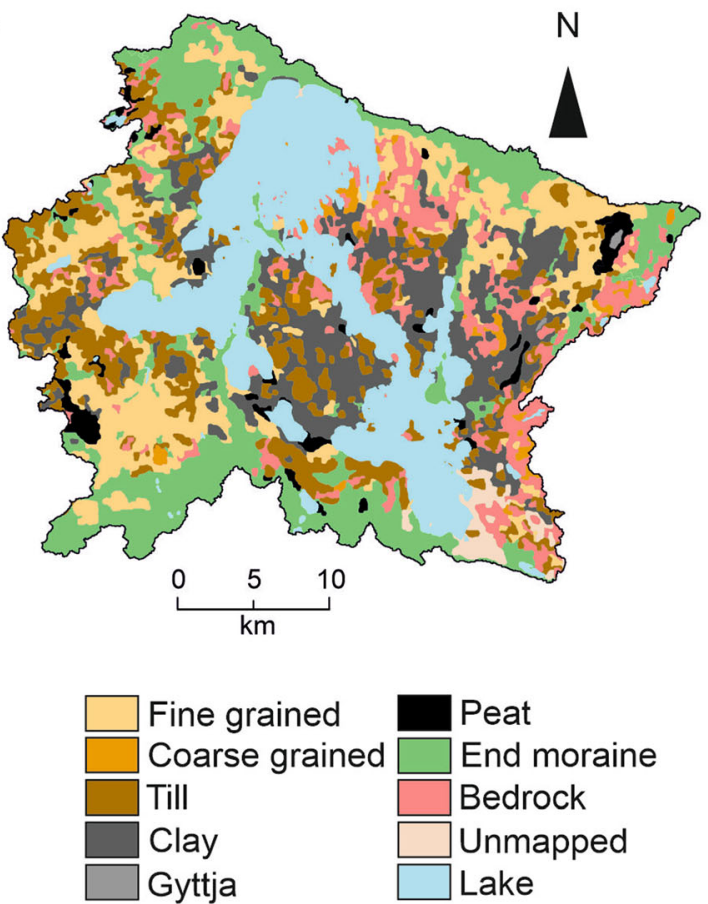

Enonsaari Deep and aerators in the Enonsaari and Lankiluoto Deeps in the Enonselkä Basin. b Land use types and $\mathbf{c}$ surface geology of the Lake Vesijärvi drainage basin

corer (Renberg and Hansson 2008), using the icefinger technique (Saarinen and Wenho 2005). Freeze cores were recovered to obtain an undisturbed 
Table 1 Selected historical $(\mathrm{H})$ events and restoration (R) actions in Lake Vesijärvi since the 17th century (Keto 1982; Keto and Sammalkorpi 1988; Liukkonen et al. 1993; Salonen et al. 2020)

\begin{tabular}{|c|c|c|c|}
\hline Event & $\begin{array}{l}\mathrm{H} / \\
\mathrm{R}\end{array}$ & Timing & Additional information \\
\hline Start of second aeration & $\mathrm{R}$ & November 2009 & $\begin{array}{l}\text { Installation of nine aerators in the southern part of the lake. The } \\
\text { number of operating aerators varied over time }\end{array}$ \\
\hline Management fishing & $\mathrm{R}$ & Since 1994 & The annual catch mass varied over time \\
\hline Harbor dredging & $\mathrm{H}$ & 1990-1991 & Clay marker layer \\
\hline Biomanipulation & $\mathrm{R}$ & $1989-1993$ & $\begin{array}{l}\text { Mass removal of planktivorous and benthivorous fish, stocking of } \\
\text { predatory fish }\end{array}$ \\
\hline First aeration & $\mathrm{R}$ & $1979-1985$ & One aerator at Lankiluoto Deep \\
\hline $\begin{array}{l}\text { Start of sewage } \\
\text { treatment }\end{array}$ & $\mathrm{R}$ & 1976 & Waste water diversion from the lake \\
\hline Boat harbor construction & $\mathrm{H}$ & $1964-1965$ & Clay marker layer \\
\hline $\begin{array}{l}\text { Establishment of ground } \\
\text { water pumping plants }\end{array}$ & $\mathrm{H}$ & 1910 and 1952 & $\begin{array}{l}\text { Establishment of the largest plants in } 1910 \text { and } 1952 \text { to supply } \\
\text { drinking water for Lahti. The latter Jalkaranta is plant } 2 \mathrm{~km} \text { from } \\
\text { the Enonsaari Deep }\end{array}$ \\
\hline $\begin{array}{l}\text { Vääksy canal } \\
\text { construction }\end{array}$ & $\mathrm{H}$ & $1868-1871$ & Water level regulation via Vääksy canal \\
\hline $\begin{array}{l}\text { Artificial lake level } \\
\text { lowering }\end{array}$ & $\mathrm{H}$ & $\begin{array}{l}\text { Several times in the } 17 \text { th, } \\
18 \text { th, and } 19 \text { th century }\end{array}$ & $\begin{array}{l}\text { River dredging and channel excavation to prevent flooding. Overall } \\
\text { lowering since } 17 \text { th century was } 3.0 \mathrm{~m}\end{array}$ \\
\hline
\end{tabular}

sediment surface sample and ensure that none of the topmost sediment was missing from the long cores.

\section{Laboratory work}

The long sediment cores were split lengthwise with a circular saw and a wire. The freeze cores, along with the cleaned sediment surfaces of the split long cores, were photographed with a Canon EOS 600D camera. 11-cm-long sub-samples, with a 1-cm overlap, were collected from the long sediment cores for freeze drying and embedding with epoxy. Freeze drying was performed with a Christ laboratory freeze dryer. Subsamples were embedded with Araldite epoxy at a pressure of -150 mbar, using the method of Lotter and Lemcke (1999). Embedded samples were cut using a rock saw and polished into 5-mm-thick slabs for microscopy and $\mu$ XRF analysis. A Nikon SMZ800 stereomicroscope, coupled with a Canon EOS 600D camera and Canon EOS Utility software, was used for varve counting, and for making varve and lamina thickness measurements on the 5-mm slabs from each
Table 2 Information on the long sediment cores (PC) and freeze cores (FC) taken from the Enonsaari Deep in March 2018 along a waterdepth transect at different distances from aerator number 5

\begin{tabular}{lllcl}
\hline Core & Core type & Water depth $(\mathrm{m})$ & Core length $(\mathrm{cm})$ & Distance from aerator 5 $(\mathrm{m})$ \\
\hline VJ1 & FC & 32.00 & 30 & 45 \\
VJ2 & PC & 32.00 & 150 & 45 \\
VJ19 & FC & 29.95 & 30 & 70 \\
VJ20 & PC & 29.95 & 167 & 70 \\
VJ21 & FC & 29.95 & 30 & 62 \\
VJ22 & PC & 29.95 & 165 & 62 \\
VJ23 & FC & 26.80 & 30 & 108 \\
VJ24 & PC & 26.80 & 155 & 108 \\
VJ25 & FC & 23.80 & 30 & 123 \\
VJ26 & PC & 23.80 & 166 & 123 \\
\hline
\end{tabular}


core. These slabs were mounted in a vacuum-operated Bruker Tornado $\mu$ XRF analyzer (voltage $50 \mathrm{kV}$, tube current $600 \mu \mathrm{A}$, distance of pixels $60 \mu \mathrm{m}$, spot size $20 \mu \mathrm{m}$, Rhodium anode) and examined by taking $2 \mathrm{D}$ elemental maps of several elements, and a continuous series of elemental (potassium $[\mathrm{K}]$ and zinc $[\mathrm{Zn}]$ ) line scans (single line, width 9 pixels), derived from the 2D elemental maps, using Esprit M4 software.

To study sediment microstructures, $50-\mu \mathrm{m}$ thin sections were prepared from the 5-mm slabs of cores VJ20 and VJ24, using an ASTERA CUT8 diamond saw and an ASTERA GRN16 grinder. For microfacies analysis, changes in abundance of biogenic and clastic components within the Lake Vesijärvi varve structure were analyzed with a Leitz Laborlux petrographic microscope, coupled with a Euromex HD-Ultra camera. For long sediment core VJ20, ${ }^{137}$ Cs activity was analyzed in a continuous series of 59 wet sediment samples, using a BrightSpec gamma spectrometer (3600 s counting time) at the Geological Survey of Finland. Each sediment sample integrated 1-2 varves.

Sediment types (varved, poorly varved, nonvarved) in core sections were identified in each core. Identification of varves and varve counting was possible for varved sections, and also for poorly varved sections, whose varve boundaries were observable, despite disturbance of their internal structure. The varve chronology for core VJ20, in calendar years, was established using four chronological marker layers, including two identified ${ }^{137} \mathrm{Cs}$ activity peaks and two prominent lithostratigraphic (clay) marker layers. These clay layers with known ages were also used to anchor the varve chronologies of the other cores and align them with VJ20. Geochemical line scan profiles of the $\mathrm{K} / \mathrm{Zn}$ ratio were also used to identify the clay layers and to confirm correlations between the cores. $\mathrm{K}$ is a terrigenous (minerogenic) element, whereas $\mathrm{Zn}$ originates mainly from industrial sources (Jilbert et al. 2020). The K/Zn ratio, therefore, represents the ratio of natural minerogenic to industrial matter in the sediment.

The durations of non-varved sections above the oldest preserved varves were estimated by calculating the varve thickness average of three varves (varved or poorly varved) above and below the non-varved section. The calculated average varve thickness was used to estimate how many varves the non-varved section represents, i.e. the duration of the non-varved section. As the earliest appearance of varve preservation and its subsequent development was of principal interest in this study, no age determinations were made for the non-varved sections below the oldest preserved varves. Age uncertainties were determined by applying the error estimation approach of Lotter and Lemcke (1999). Varve counting for varved and poorly varved sections was performed three times for each core and error estimates about the mean were calculated using the three counts.

A continuous series of 41 wet sediment samples from core VJ20 (sample volume $2 \mathrm{~cm}^{3}$, representing a $1-\mathrm{cm}$ depth increment) were taken at 4-cm intervals for analysis of diatoms, which reflect changes in epilimnetic water quality. Standard procedures (Battarbee et al. 2001) were applied for diatom slide preparation. For every sample, at least 300 diatom valves were identified to species level using an optical microscope at $1000 \times$ magnification. Identification was made using the taxonomic references of Krammer and Lange-Bertalot (1986, 1988, 1991a, b) and the updated nomenclature of Porter (2008), Spaulding et al. (2008), and Guiry and Guiry (2018). TILIA and TILIAGRAPH software (Grimm 1991) were used to plot the diatom stratigraphy. The diatom assemblages in each sample were clustered into groups using stratigraphically constrained cluster analysis (CONISS, Grimm 1987). Chrysophyte cysts were also counted.

\section{Limnological data}

Historical limnological data, obtained with a LIMNOS water sampler, included dissolved oxygen, electrical conductivity (EC), and total phosphorus (TP). Data were collected at the Enonsaari Deep monitoring site and were downloaded from the HERTTA database of the Finnish environmental administration. August and January dissolved oxygen $\left(\mathrm{mg} \mathrm{l}^{-1}\right)$ data were used as representative oxygen conditions in the water column during summer and winter stagnation, respectively. Oxygen was typically measured from 1 to $30 \mathrm{~m}$ at $5-\mathrm{m}$ intervals, and from the site with the greatest water depth $(32 \mathrm{~m})$, but there were some differences in sampling intervals and depths among the sampling times. Near-bottom ( $1 \mathrm{~m}$ above lake floor) and nearsurface ( $1 \mathrm{~m}$ below lake surface) EC $\left(\mathrm{mS} \mathrm{m}^{-1}\right)$ were compared in an effort to identify the possible accumulation of sewage with high EC in the bottom water, and used to study the relation between chemical 
compounds in sewage and both varve preservation and diatom assemblages. Near-bottom and near-surface total $\mathrm{P}\left(\mu \mathrm{g}^{-1}\right)$ data were also obtained from the database for comparison with varve preservation and diatom data.

\section{Results}

Dating and core alignment

Four age markers were identified in core VJ20 $(29.95 \mathrm{~m})$ that enabled us to constrain the chronology and tie the varve sequences to calendar years. A small peak in ${ }^{137} \mathrm{Cs}$ activity $\left(\sim 41 \mathrm{~Bq} \mathrm{~kg}^{-1}\right)$ at $108.0-110.0 \mathrm{~cm}$ (Fig. 2a) corresponds to the year 1963, the time of greatest fallout from atmospheric nuclear weapons testing. A larger ${ }^{137} \mathrm{Cs}$ peak $\left(2096 \mathrm{~Bq} \mathrm{~kg}^{-1}\right)$ at a sediment depth of $68.0-70.1 \mathrm{~cm}$ (Fig. 2a) was assigned a date of 1986, corresponding to the year of the Chernobyl nuclear accident. In this part of the world, it is common that the Chernobylderived ${ }^{137} \mathrm{Cs}$ peak is much larger than the bombderived peak (Appleby 2002; Lusa et al. 2009). A 4.0$\mathrm{cm}$-thick clay layer at a depth of 102.0-106.0 cm (clay layer 2) (Fig. 2a) is associated with harbor construction in 1964-1965, and a well-defined, 0.9-cm-thick clay layer at a sediment depth of 58.0-58.9 cm (clay layer 1) was deposited during harbor dredging in 1990-1991 (Table 1).

According to the varve chronology, core VJ20 represents approximately 80 years of sedimentation during which varve thickness varied between 5 and $40 \mathrm{~mm}$ (Fig. 2). The uppermost part of the chronology, however, floats in time (Fig. 2b) because it is non-varved. Sediment in depth intervals 39-167, 4-88, 20-165, 10-82, and 5-33 cm in cores VJ20, VJ2, VJ22, VJ24, and VJ26, respectively, were dated (Fig. 2). Ages of varves above or below the dated sediment are estimates because of the non-varved section that lies between varved or poorly varved sections. As in core VJ20, the chronology of uppermost, non-varved sediment in all the other cores from different water depths, remains floating (Figs. 2, 3a). Clay layers 1 and 2 were observed in cores VJ20, $\mathrm{VJ} 22$, and VJ24, whereas only clay layer 2 was present in cores VJ2 and VJ26 (Fig. 3). Across all cores, the $\mathrm{K} / \mathrm{Zn}$ ratio varied between 0.05 and 3.4 and peaked at the depths of clay layers 1 and/or 2 (Fig. 4). In addition to these two peaks, the $\mathrm{K} / \mathrm{Zn}$ ratio showed slowly changing values below the dated section in cores VJ2 and VJ26 (Fig. 4). Error estimates for each dated or floating section in each core varied between 0 (the lowest value) and $-9.6 \%$ (the highest value) (Table 3).

Varve characteristics and their chemical composition

Based on thin section analysis of cores VJ20 and VJ24, sediments were divided into four groups: varve type I, varve type II, poorly varved, and non-varved (Figs. 3b, 4).

Type I varves (Fig. 5) consist of clastic laminae (CL) (average thickness: $14 \mathrm{~mm}$ ) and biogenic laminae (BL) (average thickness: $5.8 \mathrm{~mm}$ ). The contact between varves is sharp. The CL consists of a mixture of clastic material (the main component), amorphous organic material (AOM), organic fragments, diatoms, vivianite, and chrysophyte cysts. Vivianite was previously identified in the cores (Jilbert et al. 2020). Clastic material is more abundant in CL than in BL, in which biogenic material is the dominant component. The transition from $\mathrm{CL}$ to $\mathrm{BL}$ is gradual. The $\mathrm{BL}$ consists of three sub-laminae: BL-a (average thickness: $1.25 \mathrm{~mm}$ ), BL-b (average thickness: $3.8 \mathrm{~mm}$ ), and BL-c (average thickness: $0.5 \mathrm{~mm}$ ). BL-a is dominated by AOM and also contains clastic material, diatoms, organic fragments, and a substantial amount of vivianite. Its upper and lower boundaries are gradual. BL-b consists mostly of diatoms, whereas the abundance of vivianite is moderate. Chrysophyte cysts are abundant in the upper part of the sub-lamina. The abundance of AOM and organic fragments decreases upwards, whereas the abundance of clastic material increases. Subsequent BL-c, with a sharp lower boundary, consists nearly entirely of AOM. The abundance of clastic material and diatoms is very small compared to that in all other sub-laminae. After storage in the cold room, these type I varved sections appeared very dark, almost black, with yellow-orange sub-laminae (possibly BL-c) in fresh sediment (Fig. 3b).

Type II varves, like varve type I (Fig. 5a, b), consist of a CL (average thickness: $16 \mathrm{~mm}$ ) and a BL (average thickness: $2 \mathrm{~mm}$ ), including BL-a and BL-b. The main differences from varve type I, are the smaller thickness of BL, mainly because of thin BL-b (average 


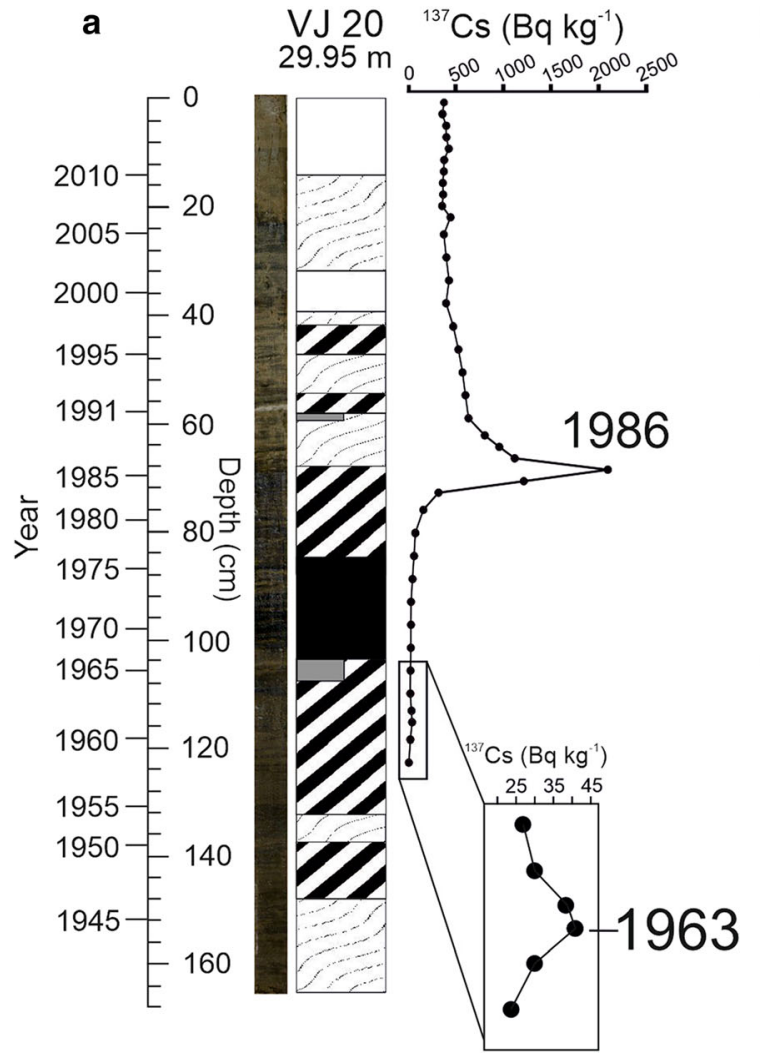

Fig. 2 a ${ }^{137}$ Cs activity and sediment types in core VJ20 plotted against sediment depth and date. Inset shows an enlargement of the $1963{ }^{137} \mathrm{Cs}$ peak b age versus sediment depth showing the

thickness: $0.14 \mathrm{~mm}$ ), and the absence of BL-c. The boundary between the BL-b and the subsequent CL is gradual in varve type II. Otherwise, the composition patterns are as in varve type I.

Poorly varved sediments have a contact between preceding BL and subsequent CL that is gradual, as described by Salminen et al. (2019). BL consist of undulating and faint BL-b, whereas BL-a and BL-c are absent.

Non-varved sediment is massive and has no identifiable laminated structure, as in Salminen et al. (2019).

XRF-derived 2D elemental maps of sulfur (S), iron $(\mathrm{Fe})$, silicon $(\mathrm{Si})$, phosphorus $(\mathrm{P})$, and potassium (K) showed laminal and sub-laminal patterns in the varved sections (Fig. 5c). $\mathrm{K}$ and $\mathrm{Fe}$ were most plentiful in $\mathrm{CL}$ in both varve types, whereas $\mathrm{Si}$ showed high abundance in CL and BL-b in varve type I. In varve type II, Si showed moderate abundance in both $\mathrm{CL}$ and $\mathrm{BL}$. In varve type I, $\mathrm{S}$ and $\mathrm{P}$ showed a b

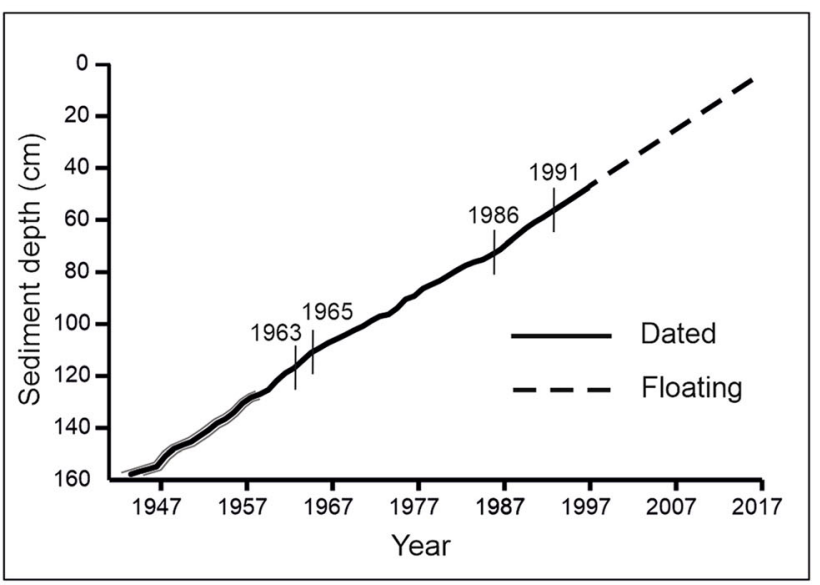

time markers used to establish the chronology. Dashed line indicates the interval of floating varve chronology and estimated varve counting error is marked with grey lines

clear peak in BL-a and BL-c, whereas in varve type II, $\mathrm{S}$ and $\mathrm{P}$ showed very weak and lesser lamina-related patterns.

\section{Depositional patterns}

Four facies were observed in cores VJ2, VJ20, VJ22, and VJ24: varve type I, varve type II, poorly varved, and non-varved (Fig. 3b). The varve type I facies was absent from core VJ26. Average varve thickness for both varve types was rather high in all cores: $19 \mathrm{~mm}$ in $\mathrm{VJ} 2,16 \mathrm{~mm}$ in $\mathrm{VJ} 20,20 \mathrm{~mm}$ in $\mathrm{VJ} 22,14 \mathrm{~mm}$ in $\mathrm{VJ} 24$, and $14 \mathrm{~mm}$ in VJ26.

The onset of varve preservation occurred at different times in each core, initiating earlier at greater water depths, then proceeding subsequently to shallower depths (Fig. 3b) and reaching the highest extent in the 1970s (Fig. 3b). The first fully preserved varves were of type II, but they were preceded by poorly varved sediment. In cores VJ2 $(32.0 \mathrm{~m})$, VJ20 and 
a

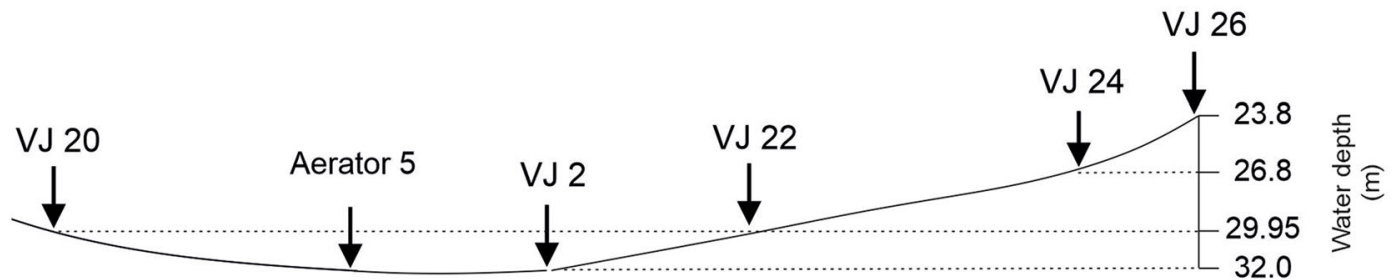

\section{b}

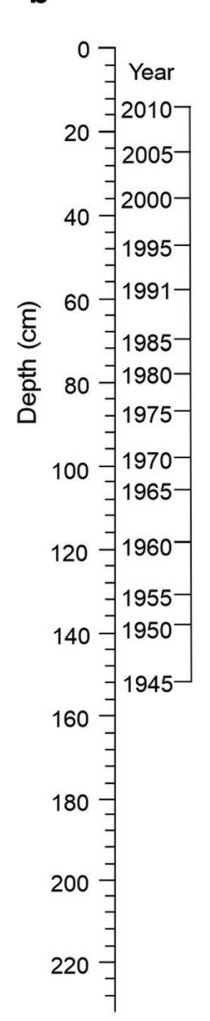

VJ 20

$(29.95 \mathrm{~m})$

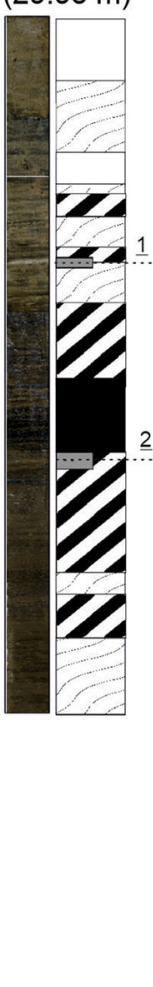

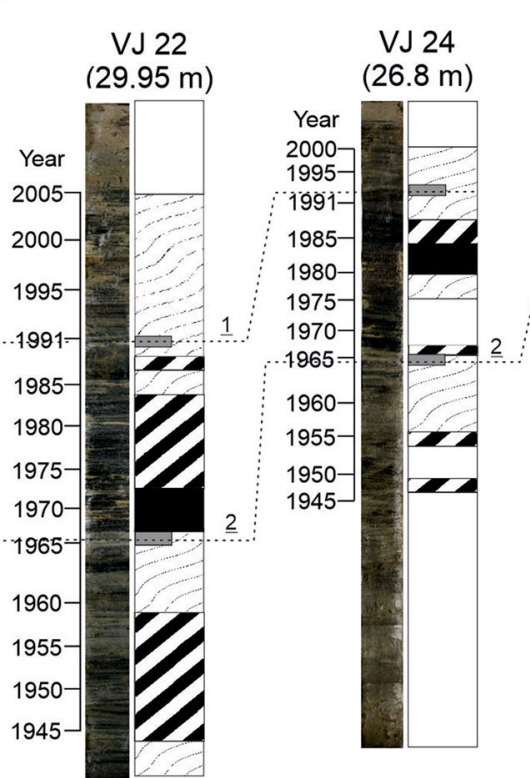

32.0

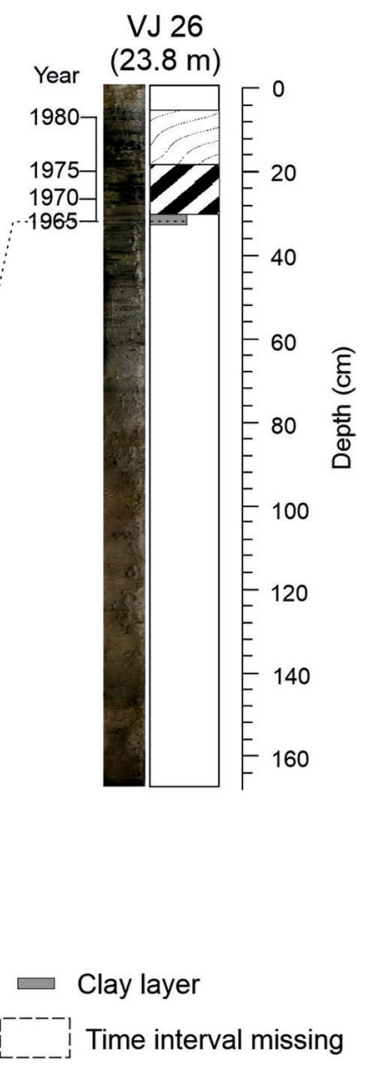

Fig. 3 a Coring sites showing their respective water depths and distances from aerator 5. b Sediment types in the cores plotted versus depth and age, and their alignments (dashed line) with one another, using clay layers 1 and 2. Photographs of split

VJ22 (29.95 m), VJ24 (26.8 m), and VJ26 (23.8 m), varve preservation started in $1939(-0.76$ to + $1.76 \%)$, the mid-1940s $(-1.20$ to $+0.51 \%$ and -1.16 to $+0.5 \%)$, the late $1940 \mathrm{~s}(-9.6$ to $+4.1 \%)$, and in $1966( \pm 0 \%)$, respectively. Type I varves appeared in the $1950 \mathrm{~s}(-0.76$ to $+1.76 \%)(\mathrm{VJ} 2$, $32.0 \mathrm{~m})$.

The termination of varve preservation is apparent in all cores. In cores VJ20, VJ 22, VJ24, and VJ26, the change from varve type I or II to non-varved was gradual, i.e. the transition included poorly varved phases, in contrast to an abrupt change, i.e. direct

sediment cores are also shown. The section missing from VJ2 is marked with a dashed rectangle. Note that all cores are plotted against a common depth scale

change from varve type I to non-varved in $\mathrm{VJ} 2$ (Fig. 3b). The gradual change from varve type I or II to non-varved sediment in cores VJ20, VJ 22, VJ24, and VJ26, lasted approximately 12, 19, 8, and 6 years, respectively. Uppermost sediment was non-varved in all cores. The thickness of this non-varved unit varied from 4.0 to $20.0 \mathrm{~cm}$ among the cores, and was generally thicker at greater water depths. The core from deepest water, VJ2 $(32.0 \mathrm{~m})$, was an exception, with only a $4.0-\mathrm{cm}$-thick non-varved section. Compared to cores VJ20, VJ22, VJ24, and VJ26, the termination of varve preservation in core VJ2 $(32.0 \mathrm{~m})$ 
seemed rapid and the uppermost record incomplete, i.e. there is a time interval missing (Fig. 3b).

Diatom analysis

Stephanodiscus parvus Stoermer and Håkansson was the most dominant diatom taxon in the Enonsaari Deep core VJ20 $(29.95 \mathrm{~m})$ during the studied period, 1939-2018 (Fig. 6). Other relatively abundant taxa included Aulacoseira islandica (Müller) Simonsen, Asterionella formosa Hassal, Fragilaria crotonensis Kitton, Aulacoseira granulata (Ehrenberg) Simonsen, Diatoma tenuis Agardh, Tabellaria fenestrata (Lyngbye) Kützing, and Staurosira construens var. venter (Ehrenberg) Hustedt. The CONISS-based clustering divided the diatom data from core VJ20 into eight groups: group 1 (1939-1940), group 2 (1941-1947), group 3 (1948-1959), group 4 (1960-1982), group 5
Fig. 5 a Detailed varve structure for varve types I and II. b Microscopy images for BL-a, BL-b, BL-c, and CL. For BL-b, varve types I and II are both shown. c Elemental distribution of $\mathrm{S}, \mathrm{Fe}, \mathrm{Si}, \mathrm{P}$, and $\mathrm{K}$ in varve types I and II. The elemental map intensity is normalized to a range between 100 (high) and 0 (low). Arrows point to cracks in the epoxy slab

(1983-1986), group 6 (1987-1998), group 7 (1999-2011), and group 8 (2012-2018) (Fig. 6). S. parvus was most abundant in groups 4,6 , and 7 and least abundant in groups 2 and 5. The relative abundance of A. formosa peaked in groups 2 and 5 . The absolute abundance of diatoms (number/ $\mathrm{ml} \times 10^{7}$ ) was highest in groups 4 and 6 , whereas the number of chrysophyte cysts relative to diatoms was highest in diatom groups 1-3. Furthermore, the thin section microfacies analysis for VJ24 showed that

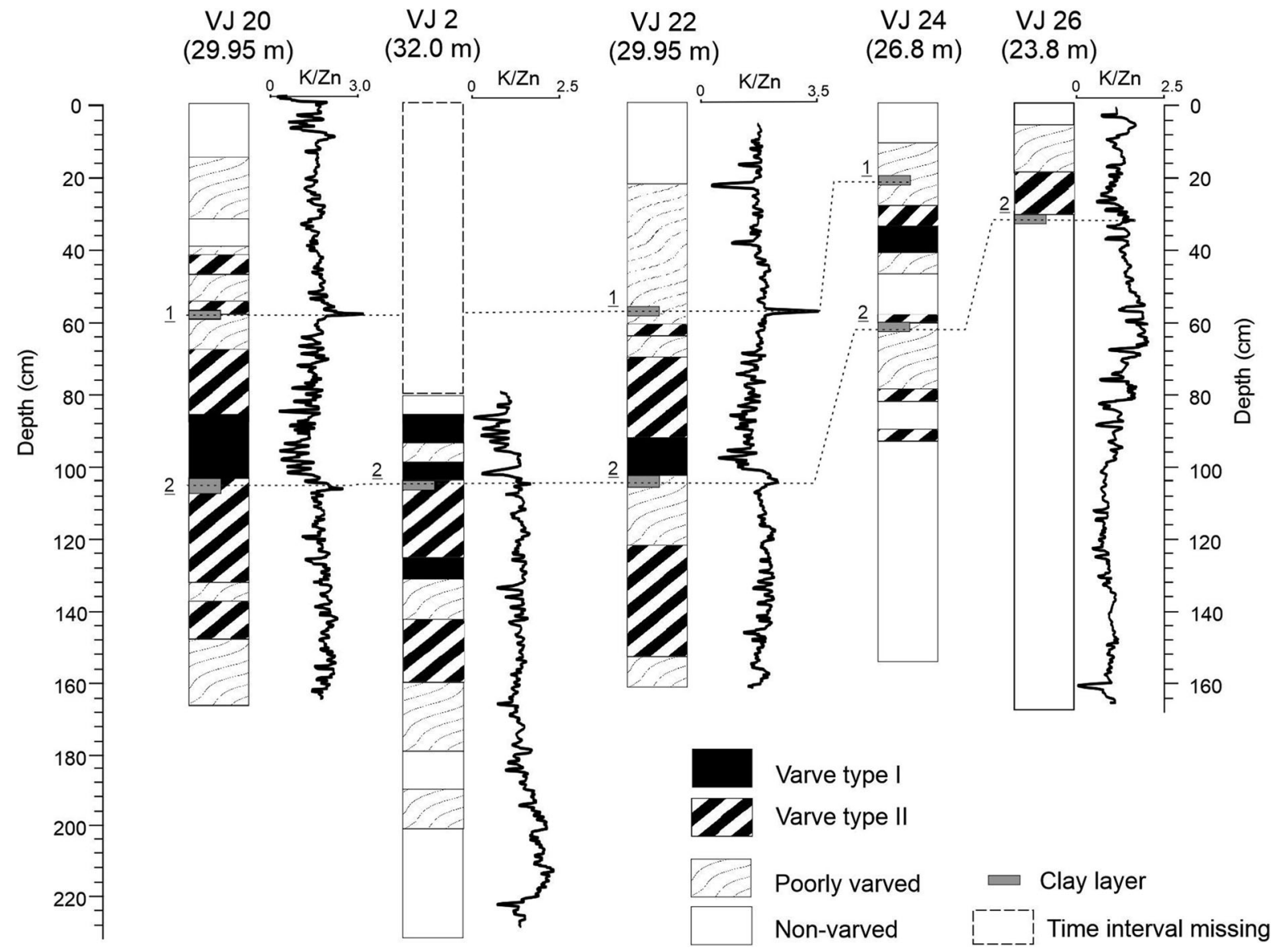

Fig. 4 Variations in K/Zn ratio, used to confirm the core alignment. Clay layers 1 and 2 in the cores are connected by dashed lines. Note that all cores are plotted against a common depth scale 


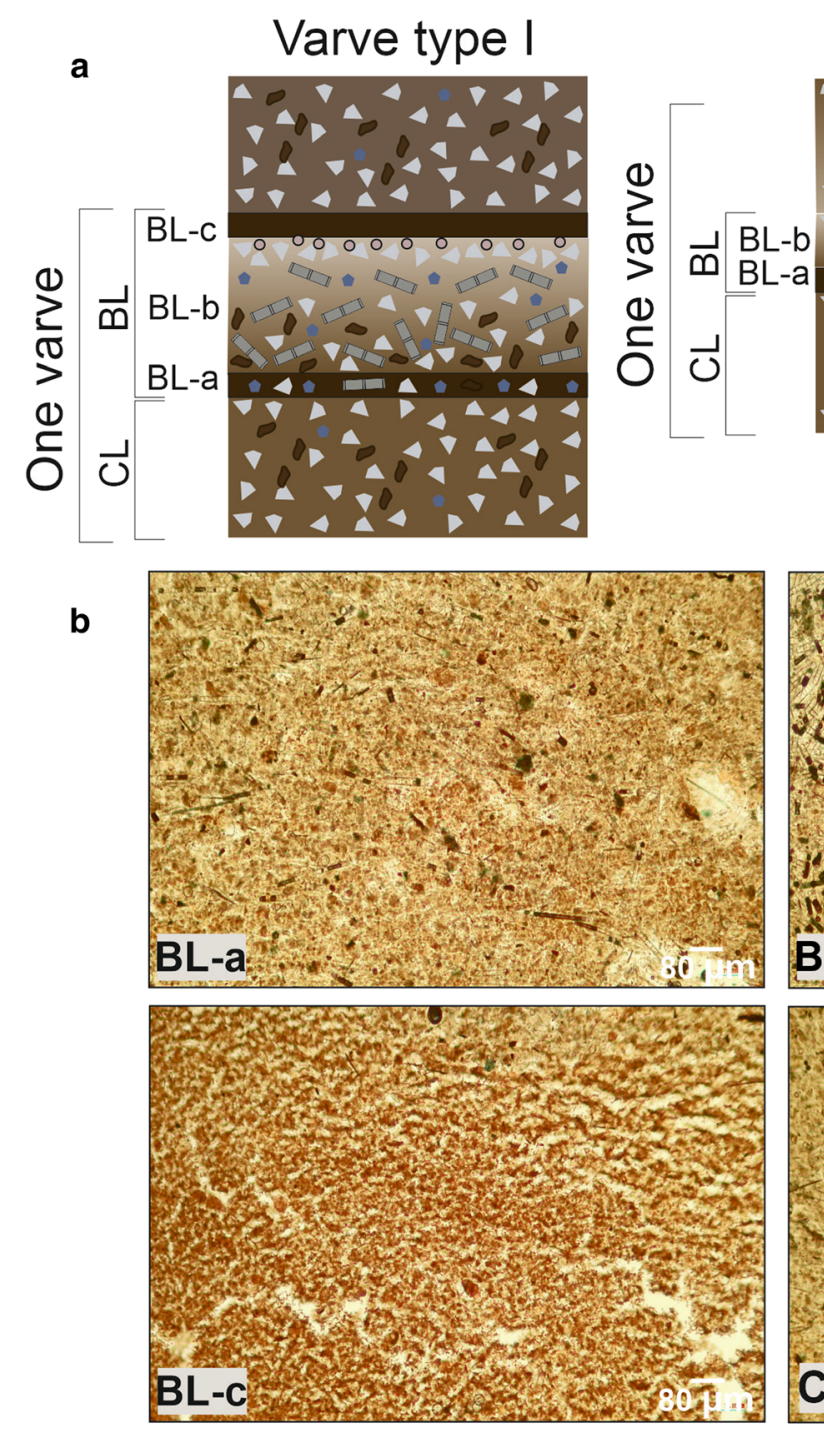

Varve type II

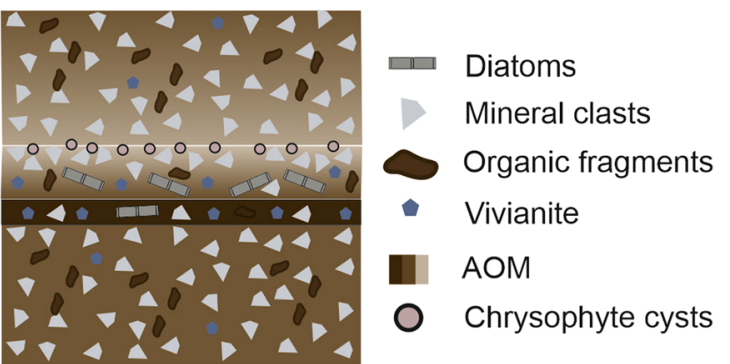

c
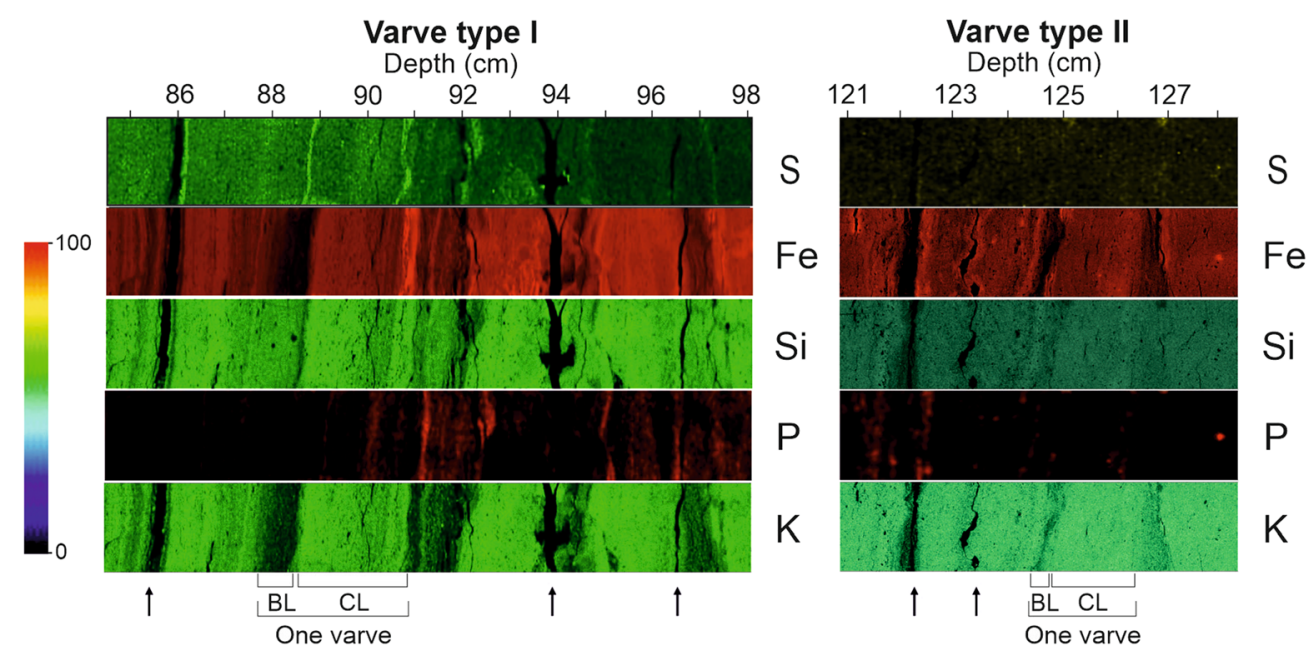
A. islandica formed the majority of areal biomass in BL-b of varve type I (Fig. 5b).

Limnological data

Since the early 1960s, water column dissolved oxygen in August varied from 0.0 to $16.0 \mathrm{mg} \mathrm{l}^{-1}$ and in January from 0.0 to $15.8 \mathrm{mg}^{-1}$, according to monitoring data from the Enonsaari Deep site (Fig. 7). The minimum water depth of hypoxic conditions $\left(\leq 2.0 \mathrm{mg} \mathrm{l}^{-1}\right.$ ) varied between 9.0 and $31.0 \mathrm{~m}$ in August and between 10.0 and $31.0 \mathrm{~m}$ in January (Fig. 7a). Near-surface EC varied from 10.0 to $28.0 \mathrm{mS} \mathrm{m}^{-1}$ and near-bottom EC from 10.0 to $30.0 \mathrm{mS} \mathrm{m}{ }^{-1}$, generally increasing before the construction of the wastewater treatment facility in 1976 and decreasing thereafter (Fig. 7b). Some minor fluctuations are superimposed on this trend. The near-surface TP varied between 16 and $150 \mu \mathrm{g} \mathrm{l}^{-1}$ and decreased from the 1970s to the mid-1990s (Fig. 7b). The near-bottom TP fluctuated from 23 to $5000 \mu \mathrm{g} 1^{-1}$. In 2010-2015, both ECs and TPs remained relatively low compared to values in previous decades.

\section{Discussion}

Onset and changes in varve preservation

The Enonsaari Deep of Lake Vesijärvi has a history of varve preservation that extends back to the late 1930s. The observations of varve preservation reflect the eutrophication history and subsequent recovery trajectory of Lake Vesijärvi. Type II varves and the preceding poorly varved sediments started to appear concurrently with evolving eutrophication and expanding hypoxia (Figs. 3b, 4, 7a). During the highly eutrophic phase and most extensive hypoxia in the 1970s (Fig. 7a), varve type I spread to shallower water depths from the deepest point (Fig. 3b). After the start of sewage diversion in 1976, varve type reverted to type II. The onset of varve preservation and hypoxia in the basin, therefore, was dependent on water depth. This was expected, given that varve preservation is generally dependent on hypoxia (Zolitschka et al. 2015), which occurs in deep water because of consumption of oxygen during organic matter mineralization. The appearance of varve preservation at shallower water depths indicates expanding hypoxia in the Enonsaari Deep during the 20th century (Figs. 3b, 7a). This type of recent onset of varve preservation,

Table 3 Error estimates for each dated (D) or floating (F) section in each core

\begin{tabular}{|c|c|c|c|c|}
\hline Core & $\begin{array}{l}\text { Section (sediment } \\
\text { depth/duration) }\end{array}$ & Marker layers in the section & $\begin{array}{l}\text { Dated (D) or floating } \\
\text { (F) chronology }\end{array}$ & Error estimate $(\%)$ and mean (years) \\
\hline \multirow[t]{2}{*}{$\mathrm{VJ} 2$} & $90-4 \mathrm{~cm} / 1936-1975$ & Clay layer 2 & $\mathrm{D}$ & $\begin{array}{l}+1.76 \%(39 \text { years }) ;-0.76 \% \\
(40 \text { years); mean } 39.7 \text { years }\end{array}$ \\
\hline & $\begin{array}{r}100-90 \mathrm{~cm} / \\
1926-1935\end{array}$ & & $\mathrm{~F}$ & $\pm 0 \%$; mean 9 years \\
\hline \multirow[t]{2}{*}{ VJ20 } & $\begin{array}{l}39-14 \mathrm{~cm} / \\
1999-2010\end{array}$ & & $\mathrm{~F}$ & $\pm 0 \%$; mean 11 years \\
\hline & $\begin{array}{l}167-39 \mathrm{~cm} / \\
1939-1998\end{array}$ & $\begin{array}{l}\text { Clay layers } 1 \text { and } 2{ }^{137} \text { Cs peaks } \\
\text { of } 1986 \text { and } 1963\end{array}$ & $\mathrm{D}$ & $\begin{array}{l}+0.51 \%(58 \text { years }) ;-1.20 \%(59 \\
\text { yeas }) ; \text { mean } 58.3 \text { years }\end{array}$ \\
\hline $\mathrm{VJ} 22$ & $\begin{array}{l}165-20 \mathrm{~cm} / \\
1944-2005\end{array}$ & Clay layers 1 and 2 & $\mathrm{D}$ & $\begin{array}{c}+0.5 \%(60 \text { years }) ;-1.16 \% \\
(61 \text { years }) ; \text { mean } 60.3 \text { years }\end{array}$ \\
\hline \multirow[t]{2}{*}{ VJ24 } & $\begin{array}{l}82-10 \mathrm{~cm} / \\
1954-2001\end{array}$ & Clay layer 1 and 2 & $\mathrm{D}$ & $\pm 0 \%$; mean 47 years \\
\hline & $\begin{array}{l}93-82 \mathrm{~cm} / \\
1946-1953\end{array}$ & & $\mathrm{~F}$ & $\begin{array}{l}+4.1 \%(7 \text { years }) ;-9.6 \% \text { ( } 8 \text { years }) \\
\text { mean } 7.3 \text { years }\end{array}$ \\
\hline VJ26 & $33-5 \mathrm{~cm} / 1966-1975$ & Clay layer 2 & $\mathrm{D}$ & $\pm 0 \%$; mean 9 years \\
\hline
\end{tabular}

Error estimates $( \pm \%)$ are presented with corresponding number of varve years (years) and varve counting means (years). The depth and duration of each section and the occurrence of marker layers in each section are provided 


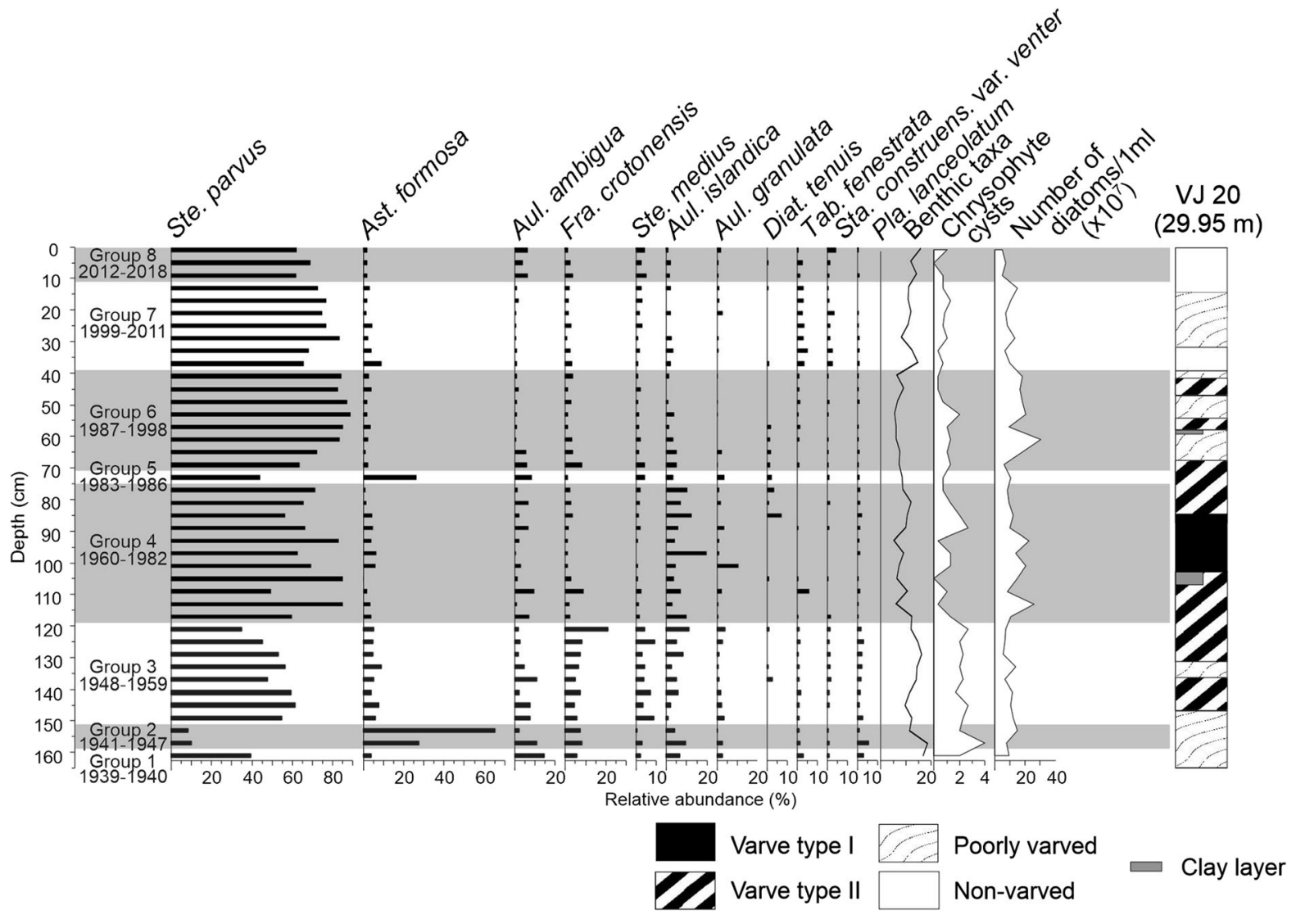

Fig. 6 Relative abundances of diatom species with relative abundances $>6 \%$ in core VJ20. The relative abundance of all benthic taxa, chrysophyte cysts relative to diatoms, and absolute abundance of diatoms are also shown. The CONISS-based

triggered by anthropogenic stressors, has been observed worldwide (Kienel et al. 2013; Rowell et al. 2015; Jenny et al. 2013, 2016a, b). Moreover, it is likely that in lakes experiencing cultural eutrophication, a climate signal can be overridden by human impact. This seems to be the case in the Enonselkä Basin, because no correlations were found between climate data and varve data from the Enonsaari Deep (unpublished data).

According to diatom assemblages in core VJ20 (Fig. 6), anthropogenic stress was already evident in the Enonsaari Deep before the sediment turned from poorly to fully varved in the 1940s. The abundance of $S$. parvus is a clear indicator of anthropogenic stress (Räsänen et al. 2006; Reavie and Cai 2019). Epilimnetic water quality seems to have changed rapidly after the onset of cultural eutrophication, which was triggered by establishment of the city of Lahti in the diatom assemblage groups (shaded) with the time periods they represent are provided, along with the corresponding sediment types. All variables are plotted versus depth in the core

early 20th century (Kairesalo and Vakkilainen 2004). Lake Vesijärvi may have been particularly susceptible to cultural eutrophication because of its location in a fertile, clay- and calcium-rich catchment (Fig. 1c; Kairesalo and Vakkilainen 2004; Tammelin et al. 2017; Tammelin and Kauppila 2018). In addition to $S$. parvus, the Enonselkä diatom record includes several other taxa, e.g. A. islandica, A. granulata, F. crotonensis, and D. tenuis, which are indicative of elevated TP and EC (Tammelin et al. 2017; Tammelin and Kauppila 2018). Some of these taxa, like A. islandica and $A$. granulata were common prior to human disturbance, in naturally eutrophic Finnish lakes, but others, such as $S$. parvus and $D$. tenuis were virtually absent prior to anthropogenic stress (Räsänen et al. 2006; Tammelin and Kauppila 2018).

Increasing rates of organic matter loading to sediments were the most likely cause of the start of 

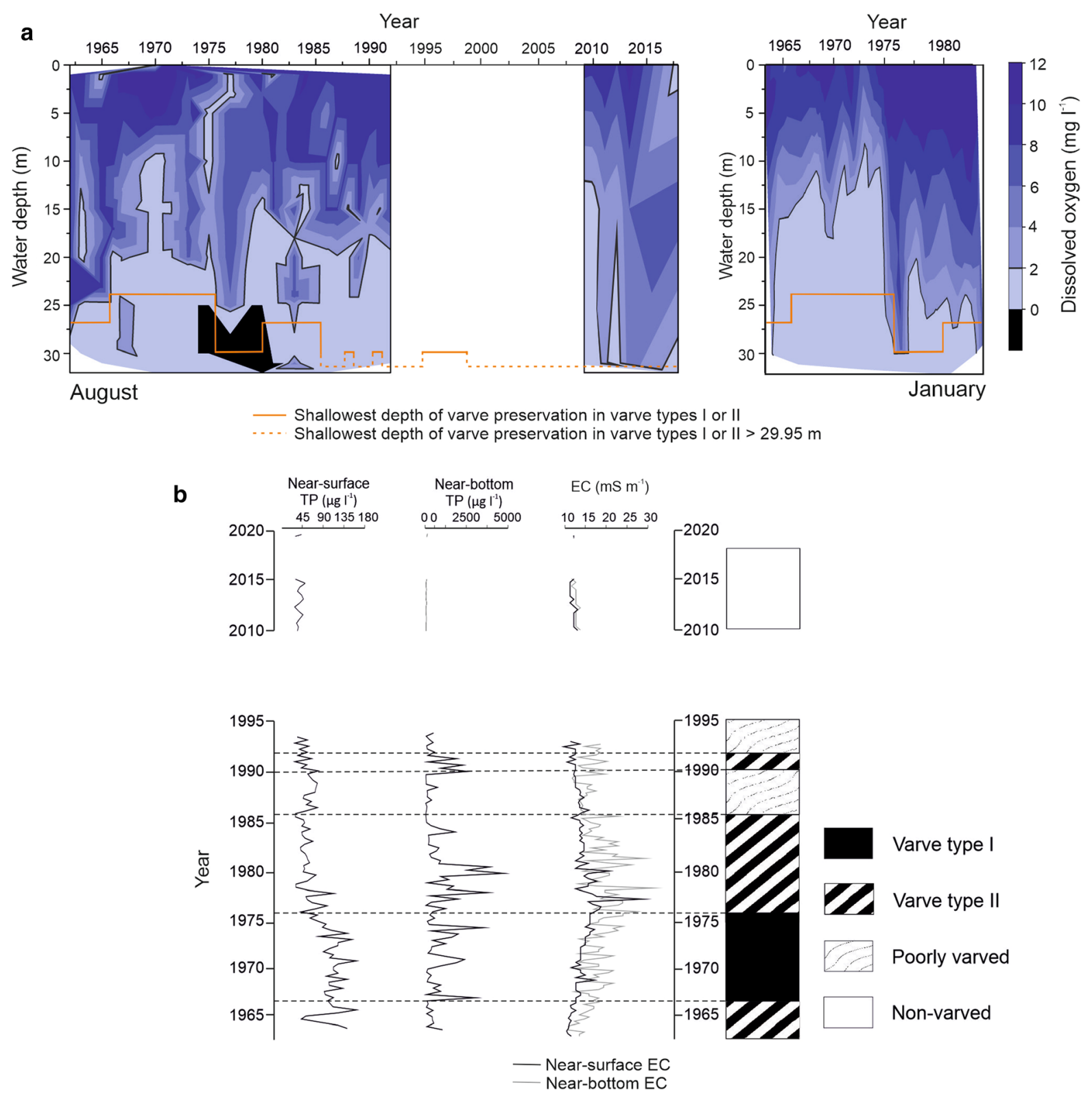

Fig. 7 a Contour plot of dissolved oxygen concentration in August and January at the Enonsaari Deep, with progression of varve types I and II at different water depths. The orange line denotes the shallowest depth of varve preservation (varve type I or II) in the studied cores at a given time. The dashed orange line indicates that the shallowest depth was $>29.95 \mathrm{~m}$, but the exact

hypolimnetic hypoxia and the onset of varve preservation in the Enonsaari Deep. Sewage loading triggers autochthonous production and increases degradation of biogenic matter, enhancing oxygen consumption and eventually leading to deep-water hypoxia (Smol depth is not known. b Total phosphorus (TP) and electrical conductivity (EC) variability at the Enonselkä water quality monitoring site plotted against age. Sediment types and their boundaries (dashed lines) for VJ20 are also provided for time periods with limnological data

2009; Müller et al. 2012; Friedrich et al. 2014). In the Lake Vesijärvi catchment, population growth in the city of Lahti, and expanded urban infrastructure, led inevitably to excessive sewage and industrial effluent discharge, until the start of sewage diversion from the 
lake in 1976 (Keto 1982). Nutrient loading gave rise to cultural eutrophication and deep-water hypoxia, and varves began to preserve at deep-water sites. By the 1960s, the Enonselkä Basin had turned from its previous clear-water state, to one of the most turbid large eutrophic lakes in Finland, characterized by massive cyanobacteria blooms (Kairesalo et al. 1999). That transition was also marked by an increase in the total abundance of diatoms and relative abundances of S. parvus and A. islandica (group 4), and a decrease in the relative abundance of chrysophyte cysts (Fig. 6), which are typically more abundant in nutrient-poor lakes with low EC (Tammelin and Kauppila 2018; Korkonen et al. 2020).

Water quality monitoring data show that hypoxia spread to water depths as shallow as $10.0 \mathrm{~m}$ during summer and $9.0 \mathrm{~m}$ during winter stagnation, during the peak period of eutrophication and hypoxia before 1976 (Fig. 7a). Simultaneously, varve preservation began at the VJ26 core site, in shallowest water (23.8 m) (Fig. 7a). Cores from even shallower water depths would be needed to determine the maximum extent over which varve preservation occurred, and the shallowest water depth at which varves were preserved during this phase of extreme hypoxia. The extent of hypoxia and varve preservation both showed declines in 1976. In addition to water depth, differences in varve preservation among cores are likely consequences of changes in the local sedimentation regime, i.e. deposition and resuspension. For example, varve preservation was not identical in cores VJ20 and VJ22, despite the fact that they represent the same water depth (Fig. 3). The lengths and numbers of different varve types in sections differ between these two cores.

The concentration of organic matter, along with the distribution in the water column of chemical compounds from industry, can influence the stability of density stratification (Boehrer and Schultze 2008), in some cases intensifying hypoxic conditions in the deep during periods of stagnation. These components may also affect the depth to which overturn occurs, by increasing the hypolimnion density (Hakala 2004), thus enhancing varve preservation. The available oxygen data, however, are not sufficient for examining the potential influence of the overturn periods on varve preservation in the Enonsaari Deep. The reduced groundwater input to the lake since the onset of groundwater pumping in the early 1950s (Keto 2010) may have further intensified the influence of sewage load on lake-bottom conditions. The near-bottom EC (Fig. 7b), an indicator of sewage loading (Oravainen 1999; Daniel et al. 2002), suggests that high-EC sewage accumulated in the bottom water of the Enonsaari Deep, possibly leading to a higher density difference between bottom and surface waters during the time of varve preservation. During the 2010s, the difference between near-bottom and near-surface EC declined simultaneously with weakening varve preservation (Fig. 7a). A similar trend in the influence of industrial waste water discharge on the Enonsaari Deep sediments was reported by Jilbert et al. (2020), as reflected by an increase in sediment $\mathrm{Zn}$ contents until 1975, and a decrease since the start of sewage treatment in 1976.

The high values of near-bottom TP, compared to near-surface TP, suggest intensified internal nutrient loading in the Enonsaari Deep during varve preservation (Fig. 7b). P is easily released from the sediments into the water under hypoxic conditions (Einsele 1936; Mortimer 1941). Hypoxia, and consequent internal loading, however, cannot have been the primary driver of eutrophication of the Enonselkä Basin (Salmi et al. 2014), because most of the TP originates from sediment resuspension in shallower areas of the lake (Niemistö et al. 2012). Abundant benthivorous fish could have enhanced internal nutrient loading prior to biomanipulation, as such fish promote sediment resuspension (Scheffer et al. 2003). Therefore, varve preservation was likely affected by changes in nutrient and sediment resuspension related to anthropogenic actions, such as harbor construction in 1964-1965 and dredging in 1990-1991, biomanipulation in 1989-1993, and subsequent management fishing (Table 1, Figs. 3b, 7a).

Harbor construction and dredging seem to have had an effect on varve preservation that was opposite to that of biomanipulation and subsequent management fishing. Mechanical disturbance of sediments during harbor construction and dredging, although $4.8 \mathrm{~km}$ from the sampling site, may have promoted varve preservation by resuspending sediment and nutrients into the water column, thereby enhancing primary production and oxygen consumption. Biomanipulation and management fishing, on the other hand, may have contributed to weakened or interrupted varve preservation. These weaker conditions for varve preservation could have been the result of reduced degradation of organic matter and oxygen 
consumption, following a decline in primary productivity, after the start of biomanipulation (Kairesalo et al. 1999). Biomanipulation also resulted in reduced nutrient recycling and fish-mediated transport of phosphorus from the littoral to the pelagic zone (Kairesalo et al. 1999) and possibly reduced fishfacilitated sediment resuspension in the shallow areas (Scheffer et al. 2003).

Varve characteristics and seasonal patterns

Varve thickness, which averaged $19 \mathrm{~mm}$ at the deepest point of the basin, is unusually high compared to values recorded in most varve-preserving Finnish lakes, which are typically a few millimeters at most (Ojala et al. 2000; Saarni 2017). In both varve types I and II, the CL results probably from snow and ice melt. This is seen in microscopy images as a high abundance of clastic material (Fig. 5b) and in elemental maps (Fig. 5c) as richness in terrigenous elements (K, Fe, and $\mathrm{Si}$ ) that were eroded from the catchment.

The high abundance of AOM in BL-a results from primary production in spring. Because of the iron sulfide mineralization pathway in OM-rich sediments (Holmer and Storkholm 2001), S is associated with AOM-rich laminae, like BL-a. P burial was also observed in this lamina (Fig. 5c). Oxide-bound $\mathrm{P}$ and authigenic vivianite are both likely components of this $P$ burial in Lake Vesijärvi (Jilbert et al. 2020). Vivianite in the AOM-rich BL-a was most likely precipitated after deposition, in response to organic matter remineralization. In both varve types, clastic material in BL-a (Fig. 5) may have been resuspended in shallow areas of the lake basin during spring overturn and transported to deeper areas, as described by Niemistö et al. (2012). Such sediment focusing of resuspended material in the Enonselkä Basin is a significant part of suspended solids in the basin (Tammeorg et al. 2013).

The abundance of diatoms and AOM in BL-b (varve types I and II) reflects lacustrine production during the growing season. Diatoms are particularly abundant in BL-b sub-lamina of varve type I (Fig. 5), in which A. islandica forms the majority of areal biomass (Fig. 5b). This high diatom abundance is also reflected in high $\mathrm{Si}$ concentrations in these sublaminae. A. islandica dominated total diatom biomass in the 1960s through the 1980s (Liukkonen et al. 1993, 1997), although $S$. parvus is the most numerous species in the diatom record of VJ20 (Fig. 6). Together, S. parvus and A. islandica form the majority of the spring diatom bloom in the Enonselkä Basin (Liukkonen et al. 1993, 1997; Salmi and Salonen 2016). S. parvus is already abundant prior to ice breakup, whereas $A$. islandica requires the higher turbulence of spring overturn to reach its maximum abundance (Liukkonen et al. 1993; Salmi and Salonen 2016). A. islandica may be particularly abundant during spring when snow persists until ice break-up, but is present throughout the growing season (Liukkonen et al. 1993). Primary production in the Enonselkä Basin is higher during spring and late summer, compared to early summer, and is associated strongly with autotrophic picoplankton (Bręk-Laitinen et al. 2012). The last sub-lamina, BL-c, in varve type $I$ is composed nearly totally of AOM, which may have originated from late summer blooms and accumulated under ice cover during winter.

As varve preservation is dependent on the local sedimentation regime, in addition to water depth, differences between varve types I and II could be a function of both. Thinner BL-b and lower abundance of diatoms in varve type II (Fig. 5) compared to varve type I, could indicate lower biogenic production during the growing season, reduced preservation of AOM because of higher oxygen concentrations, or increased human-induced resuspension in the littoral zone. The absence of BL-c in varve type II may result from these same factors.

The end of varve preservation

Water quality improvement in the Enonselkä Basin is mainly attributed to reduced external nutrient loads (Salonen et al. 2020), and the start of sewage diversion from the lake in 1976 had a noticeable impact on varve preservation, although it did not terminate it. Sewage diversion resulted in a change in sediment type in each core, as well as a decline in the extent of varve preservation (Fig. 3). A transient decrease in total diatom abundance and the relative abundance of $S$. parvus also occurred after the wastewater diversion, and again later in the 2000s and 2010s, as varve preservation weakened (Fig. 6). It appears, however, that the influence of the first aeration in the adjacent Lankiluoto Deep (approximately $1.2 \mathrm{~km}$ from the Enonsaari Deep) in 1979-1985, did not affect the Enonsaari Deep, or at least the water depths where 
varves were preserved during that time interval in our cores.

Varve preservation did not end completely during the period of biomanipulation and management fishing, although those efforts may have contributed to the weakening of varve preservation, which had already started prior to the onset of biomanipulation in 1989. In addition to reducing nutrient concentrations and primary productivity (Kairesalo et al. 1999), biomanipulation increased zooplankton grazing pressure in the Enonselkä Basin (Nykänen et al. 2010; Anttila et al. 2013). Grazing pressure can influence diatom abundance and species composition in the sediment record, in that small diatoms (e.g. S. parvus) are more likely to be grazed than larger diatoms (Wigdahl-Perry et al. 2017). The collapse of cyanobacterial blooms and increased transparency in the 1990s, following the biomanipulation, however, seems to have benefited the early spring bloomer $S$. parvus (Liukkonen et al. 1993; Salmi and Salonen 2016) more than summerblooming diatom taxa such as $F$. crotonensis and $T$. fenestrata (Liukkonen et al. 1993, 1997; Keto and Tallberg 2000). A. islandica, the other important spring bloomer, which dominated the total diatom biomass of the Enonselkä Basin until biomanipulation (Liukkonen et al. 1993, 1997), decreased in abundance. The increase in the relative abundance of benthic diatoms (e.g. S. construens var. venter) since the 1990s (Fig. 6, groups 7-8) was probably related to the expansion of macrophytes and littoral zooplankton, after biomanipulation (Nykänen et al. 2010).

The termination of varve preservation in the sediment cores typically occurred gradually, beginning after the start of sewage treatment. The termination incorporated interruptions of varve preservation and generally proceeded from varved to poorly varved and finally to non-varved sediment. Core VJ2 (water depth $32.0 \mathrm{~m}, 45.0 \mathrm{~m}$ from the aerator) was an exception to the gradual termination of varve preservation. In VJ2, the change from varved to non-varved sediment was rapid. This quick change, along with core correlation, absence of clay layer 1 , and absence of a poorly varved section on top of the uppermost varve type I section in VJ2 (Figs. 3b, 4), indicate that there is a missing time interval in the topmost part of the core. No sediment was lost during sampling, as documented by comparison between this core and the freeze core from the same sampling site. Thus, sedimentation dynamics at this site probably changed dramatically, from a period of continuous deposition, to an episode of no accumulation, or even erosion of the recent, near-surface sediment section.

The change in sedimentation at $\mathrm{VJ} 2$, the site closest to the aerator, was probably a response to enhanced turbulence caused by pumping of oxygen-rich surface water into the hypolimnion since 2010. Increased turbulence was observed at distances of 20-200 m from another aerator in the Enonselkä Basin (Niemistö et al. 2016). Aerator-induced water mixing also prevented stable summer stratification in the basin (Salmi et al. 2014). These changes in water column conditions seem to have modified the location of the sediment accumulation zone in the Enonsaari Deep, and perhaps promoted development of a transport or erosional zone, at a distance of $45 \mathrm{~m}$ from the aerator. Similarly, Liukkonen et al. (1993) observed a change in varve preservation in the Lankiluoto Deep of Lake Vesijärvi during the first aeration in 1979-1985, when an aerator was located at that deep. Sediment trap studies from the Enonselkä Basin, however, suggest increased organic matter sedimentation and intensified phosphorus recycling during the second aeration, caused by an increase in turbulence and water temperature (Niemistö et al. 2016, 2019). At our sampling sites, located farther from the aerator, aeration-induced stratification break-up seems to be linked to the transition from poorly varved to nonvarved sediment.

Aeration-amplified turbulence is also capable of extending spring diatom blooms (Webb et al. 1997), but the second aeration seems to have had a negligible influence on the spring diatom community composition, a consequence of natural convection overriding mechanical mixing (Salmi and Salonen 2016). In addition to increasing nutrient recycling in the Enonselkä Basin (Niemistö et al. 2016, 2019), the second aeration reduced zooplankton grazing pressure $(\mathrm{Ru}-$ uhijärvi et al. 2020), contrary to the effects of biomanipulation. The reason for A. formosa peaking at the end of the first aeration (group 5), and prior to restoration actions in the 1940 s, but not during the second aeration, remains unclear. This species may benefit from turbulent spring conditions (Liukkonen et al. 1993; Webb et al. 1997), but its low sinking rate can also make it competitive during thermal stratification (Sivarajah et al. 2016). Nevertheless, the dominance of $S$. parvus in the most recent sediments indicates a continuing legacy of anthropogenic stress 
in the Enonselkä Basin, despite the restoration actions, improved water quality, and termination of varve preservation.

\section{Conclusions}

Varve analysis of multiple sediment cores, taken along a water-depth transect in the Enonsaari Deep, revealed that Lake Vesijärvi experienced a short varve preservation history that began in the late 1930s and continued until the 2000s. In the most distinguishable varves (varve type I), three biogenic sub-laminae (BL$a, B L-b$, and BL-c) were observed, in addition to the clastic lamina (CL). The abundance of diatoms was unexpectedly high in BL-b compared to the less pronounced varves (type II), which also lack the BL-c sub-lamina.

Varve preservation was triggered by increased sewage loading and varied subsequently because of restoration efforts and other anthropogenic activities. These activities in the lake and its catchment included sewage diversion from the lake, infrastructure construction, biomanipulation, and groundwater withdrawals. Varve preservation began during intensifying sewage loading, at first with poorly varved sediment, and followed by the occurrence of varve type II. Varve type I represents the period of maximum sewage loading. After the start of sewage diversion in the mid1970s, varve type I changed back to varve type II, and thereafter sediments were poorly varved and finally non-varved. Despite the improved water quality since the mid-1970s, diatom assemblages of the Enonsaari Deep suggest a continued legacy of anthropogenic stressors that continues today. Of all restoration actions, aeration in the 2010s had the single greatest impact on varve preservation and sedimentation dynamics in the Enonsaari Deep. It seems to have terminated varve preservation in the deep and resulted in the transformation of a sediment accumulation zone into a transport or erosional zone in the vicinity of the aerator.

Acknowledgements This study was funded by Maa- ja vesitekniikan tuki ry., the Finnish Concordia Fund, and the Finnish Society of Sciences and Letters (The Sohlberg delegation). The sediment coring on Lake Vesijärvi was funded by the Lake Vesijärvi Foundation. We thank Timo Saarinen, Sami Jokinen, and Arto Peltola for their help in sediment coring. We thank Timo Saarinen, Jouni Kolhinen, and
Sören Fröjdö for conducting the $\mu$ XRF measurements and Arto Peltola for teaching us how to prepare thin sections. Furthermore, we thank Niina Kuosmanen for her feedback.

Funding Open access funding provided by University of Turku (UTU) including Turku University Central Hospital.

Open Access This article is licensed under a Creative Commons Attribution 4.0 International License, which permits use, sharing, adaptation, distribution and reproduction in any medium or format, as long as you give appropriate credit to the original author(s) and the source, provide a link to the Creative Commons licence, and indicate if changes were made. The images or other third party material in this article are included in the article's Creative Commons licence, unless indicated otherwise in a credit line to the material. If material is not included in the article's Creative Commons licence and your intended use is not permitted by statutory regulation or exceeds the permitted use, you will need to obtain permission directly from the copyright holder. To view a copy of this licence, visit http://creativecommons.org/licenses/by/4.0/.

\section{References}

Anttila S, Ketola M, Kuoppamäki K, Kairesalo T (2013) Identification of a biomanipulation-driven regime shift in Lake Vesijärvi: implications for lake management. Freshw Biol 58:1494-1502

Appleby PG (2002) Chronostratigraphic techniques in recent sediments. In: Last WM, Smol JP (eds) Tracking environmental change using lake sediments, vol 1. Kluwer Academic Publishers, Dordrecht, pp 171-203

Artimo A, Kajander S, Saraperä S, Puurunen O (2012) Lahden ja Hollolan alueen pohjaveden virtausmallin päivitys. Lahti Aqua Oy and Lahden kaupunki

Ahti T, Hämet-Ahti L, Jalas J (1968) Vegetation zones and their sections in northwestern Europe. In: Annales Botanici Fennici, pp 169-211

Battarbee RW, Jones VJ, Flower RJ, Cameron NG, Bennion H, Carvalho L, Juggins S (2001) Diatoms. In: Smol JP, Birks HJB, Last WM (eds) Tracking environmental change using lake sediments, vol 3. Kluwer Academic Publishers, Dordrecht, pp 155-202

Baulch HM, Schindler DW, Turner MA, Findlay DL, Paterson MJ, Vinebrooke RD (2005) Effects of warming on benthic communities in a boreal lake: implications of climate change. Limnol Oceanogr 50:1377-1392

Boehrer B, Schultze M (2008) Stratification of lakes. Rev Geophys 46

Bręk-Laitinen G, López Bellido J, Ojala A (2012) Response of a microbial food web to prolonged seasonal hypoxia in a boreal lake. Aquat Biol 14:105-120

Daniel MH, Montebelo AA, Bernardes MC, Ometto JP, De Camargo PB, Krusche AV, Bellester MV, Victoria RL, Martinelli LA (2002) Effects of urban sewage on dissolved 
oxygen, dissolved inorganic and organic carbon, and electrical conductivity of small streams along a gradient of urbanization in the Piracicaba river basin. Water Air Soil Pollut 136:189-206

Diaz RJ (2001) Overview of hypoxia around the world. J Environ Qual 30:275-281

Einsele W (1936) Über die beziehungen des eisenkreislaufs zum phosphatkreislauf im eutrophen see. Arch Hydrobiol 29:664-686

Eurofins Environment Testing Projekti 1820007 5.11.2019. Vesijärven tila vuonna (2018). Available online: https:// www.vesijarvi.fi/wp-content/uploads/Vesij\%C3\% A4rvitarkkailu_2018_raportti-liitteineen.pdf. Accessed on 14 Apr 2020

FEI database - Finnish Environment Institute database. Corine land cover. Available online: https://www.avoindata.fi/ data/en_GB/dataset/corine-maanpeite-2018. Accessed on 14 Apr 2020

FMI database - Finnish Meteorological Institute database. Available online: https://en.ilmatieteenlaitos.fi/statisticsfrom-1961-onwards. Accessed on 14 Apr 2020

Friedrich J, Janssen F, Aleynik D, Bange HW, Boltacheva N, Çagatay MN, Dale AW, Etiope G, Erdem Z, Geraga M et al (2014) Investigating hypoxia in aquatic environments: diverse approaches to addressing a complex phenomenon. Biogeosciences 11:1215-1259

Giguet-Covex C, Arnaud F, Poulenard J, Enters D, Reyss JL, Millet L, Lazzaroto J, Vidal O (2010) Sedimentological and geochemical records of past trophic state and hypolimnetic anoxia in large, hard-water Lake Bourget, French Alps. J Paleolimnol 43:171-190

Grimm E (1991) TILIA and TILIAGRAPH pollen diagramming program. Ill State Mus Springf

Grimm EC (1987) CONISS: a FORTRAN 77 program for stratigraphically constrained cluster analysis by the method of incremental sum of squares. Comput Geosci 13:13-35

Guiry MD, Guiry GM (2018) AlgaeBase. World-Wide Electronic Publication, National University of Ireland, Galway. Available online: http://www.algaebase.org. Accessed on 4 June 2020

Hakala A (2004) Meromixis as a part of lake evolution; observations and a revised classification of true meromictic lakes in Finland. Boreal Environ Res 9:37-53

Hernández-Almeida I, Grosjean M, Gómez-Navarro JJ, Larocque-Tobler I, Bonk A, Enters D, Ustrzycka A, Piotrowska N, Przybylak R, Wacnik A, Witak M, Tylmann W (2017) Resilience, rapid transitions and regime shifts: Fingerprinting the responses of Lake Żabińskie (NE Poland) to climate variability and human disturbance since AD 1000. Holocene 27:258-270

HERTTA database. Available online: https://www.syke.fi/enUS/Open_information. Accessed on 15 Mar 2019

Holmer M, Storkholm P (2001) Sulphate reduction and sulphur cycling in lake sediments: a review. Freshw Biol 46:431-451

Horppila J, Kairesalo T (1990) A fading recovery: the role of roach (Rutilus rutilus L.) in maintaining high phytoplankton productivity and biomass in Lake Vesijärvi, southern Finland. Hydrobiologia 200/201. pp 153-165
Horppila J, Peltinen H, Malinen T, Luokkanen E, Kairesalo T (1998) Top-down or bottom-up effect by fish: issues of concern in biomanipulation on lakes. Restor Ecol 6:20-28

Jenny JP, Normandeau A, Francus P, Taranu ZE, GregoryEaves I, Lapointe F, Jautzy J, Ojala AEK, Dorioz JM, Schimmelmann A, Zolitschka A (2016) Urban point sources of nutrients were the leading cause for the historical spread of hypoxia across European lakes. PNAS 113:12655-12660. https://doi.org/10.1073/pnas. 1605480113

Jenny JP, Francus P, Normandeau A, Lapointe F, Perga ME, Ojala AEK, Schimmelmann A, Zolitschka B (2016) Global spread of hypoxia in freshwater ecosystems during the last three centuries is caused by rising local human pressure. Glob Change Biol 22:1481-1489. https://doi.org/10.1111/ gcb. 13193

Jenny JP, Arnaud F, Dorioz JM, Giguet Covex C, Frossard V, Sabatier P, Millet L, Reyss JL, Tachikawa K, Bard E et al (2013) A spatiotemporal investigation of varved sediments highlights the dynamics of hypolimnetic hypoxia in a large hard-water lake over the last 150 years. Limnol Oceanogr 58:1395-1408

Jilbert T, Jokinen S, Saarinen T, Mattus-Kumpunen U, Simojoki A, Saarni S, Salminen S, Niemistö J, Horppila J (2020) Impacts of a deep reactive layer on sedimentary phosphorus dynamics in a boreal lake recovering from eutrophication. Hydrobiologia. https://doi.org/10.1007/s10750020-04289-9

Kairesalo T, Vakkilainen K (2004) Lake Vesijärvi and the city of Lahti (southern Finland) comprehensive interactions between the lake and the coupled human community. SIL News 41:1-5

Kairesalo T, Laine S, Luokkanen E, Malinen T, Keto J (1999) Direct and indirect mechanisms behind successful biomanipulation. Hydrobiologia 395:99-106

Keto J (2010) Järvi ennen ja nyt. In: Keto J, Kolunen H, Pekkarinen A, Tuominen L (ed) Vesijärvi-Salpausselkien tytär. Lahden seudun ympäristöpalvelut \& Vesijärvisäätiö, pp 11-31

Keto J, Tallberg P (2000) The recovery of Vesijärvi, a lake in southern Finland: water quality and phytoplankton interpretations. Boreal Environ Res 5:15-26

Keto J, Sammalkorpi I (1988) fading recovery: A conceptual model for Lake Vesijärvi management and research. Aqua Fenn 18:193-204

Keto J (1982) The recovery of Lake Vesijärvi after sewage diversion. Hydrobiologia 86:195-199

Kienel U, Dulski P, Ott F, Lorenz S, Brauer A (2013) Recently induced anoxia leading to the preservation of seasonal laminae in two NE-German lakes. J Paleolimnol 50:535-544

Korkonen S, Weckström J, Korhola A (2020) Biogeography and ecology of freshwater chrysophyte cysts in Finland. Hydrobiologia 847:487-499

Krammer K, Lange-Bertalot H (1986) Bacillariophyceae, teil: naviculaceae. In: Ettle H, Gerloff J, Heynig H, Mollenhauer D (eds) Süsswasserflora von mitteleuropa. Fischer, New York (Band 2/1)

Krammer K, Lange-Bertalot H (1988) Bacillariophyceae, teil: bacillariaceae, epithemiaceae, surirellaceae. In: Ettle $\mathrm{H}$, 
Gerloff J, Heynig H, Mollenhauer D (eds) Süsswasserflora von mitteleuropa. Fischer, Stuttgart, New York (Band 2/2)

Krammer K, Lange-Bertalot H (1991) Bacillariophyceae, teil: centrales, fragilariaceae, eunotiaceae. In: Ettle H, Gerloff J, Heynig H, Mollenhauer D (eds) Süsswasserflora von mitteleuropa. Fisher, Stuttgart, Jena (Band 2/3)

Krammer K, Lange-Bertalot H (1991) Bacillariophyceae, teil: achnanthaceae. In: Ettle H, Gartner G, Gerloff J, Heynig H, Mollenhauer D (eds) Süsswasserflora von mitteleuropa. Fisher, Stuttgart, Jena (Band 2/4)

Last WM, Smol JP (2001) An introduction to physical and geochemical methods used in paleolimnology. In: Last WM, Smol JP (eds) Tracking environmental change using lake sediments. Basin analysis, coring, and chronological techniques, vol 1. Kluwer Academic Publishers, Dordrecht, pp 1-5

Liukkonen M, Kairesalo T, Keto J (1993) Eutrophication and recovery of Lake Vesijärvi (south Finland): diatom frustules in varved sediments over a 30 -year period. Hydrobiologia 269:415-426

Liukkonen M, Kairesalo T, Haworth EY (1997) Changes in the diatom community, including the appearance of Actinocyclus normanii f. subsalsa, during the biomanipulation of Lake Vesijärvi. Finland Eur J Phycol 32:353-361

Lotter AF, Lemcke G (1999) Methods for preparing and counting biochemical varves. Boreas 28:243-252

Lusa M, Lehto J, Leskinen A, Jaakkola T (2009) 137Cs, 239,240 $\mathrm{Pu}$ and 241 Am in bottom sediments and surface water of Lake Päijänne, Finland. J Environ Radioact 100:468-476

Mortimer CH (1941) The exchange of dissolved substances between mud and water in lakes. J Ecol 29:280-329

Müller B, Bryant LD, Matzinger A, Wüest A (2012) Hypolimnetic oxygen depletion in eutrophic lakes. Environ Sci Technol 46:9964-9971

Niemistö J, Silvonen S, Horppila J (2019) Effects of hypolimnetic aeration on the quantity and quality of settling material in a eutrophied dimictic lake. Hydrobiologia. https://doi.org/10.1007/s10750-019-04160-6

Niemistö J, Köngäs P, Härkönen L, Horppila J (2016) Hypolimnetic aeration intensifies phosphorus recycling and increases organic material sedimentation in a stratifying lake: effects through increased temperature and turbulence. Boreal Environ Res 21:571-587

Niemistö J, Tamminen P, Ekholm P, Horppila J (2012) Sediment resuspension: rescue or downfall of a thermally stratified eutrophic lake? Hydrobiologia 686:267-276

Nykänen M, Malinen T, Vakkilainen K, Liukkonen M, Kairesalo $\mathrm{T}$ (2010) Cladoceran community responses to biomanipulation and re-oligotrophication in Lake Vesijärvi, Finland, as inferred from remains in annually laminated sediment. Freshw Biol 55:1164-1181

Ojala AE, Saarinen T, Salonen VP (2000) Preconditions for the formation of annually laminated lake sediments in southern and central Finland. Boreal Environ Res 5:243-255

Oravainen R (1999) Vesistötulosten tulkinta -opasvihkonen. Kokemäenjoen vesistön suojeluyhdistys ry

Pekkarinen A (2010) Vesijärven historiaa. In: Keto J, Kolunen H, Pekkarinen A, Tuominen L (eds) Vesijärvi-Salpausselkien tytär. Lahden seudun ympäristöpalvelut \& Vesijärvisäätiö, pp 11-31
Porter SP (2008) Algal attributes: an autecological classification of algal taxa collected by the national water-quality assessment program. US Geological Survey Data Series, p 329

Reavie ED, Cai M (2019) Consideration of species-specific diatom indicators of anthropogenic stress in the Great Lakes. PLoS ONE 14:e0210927. https://doi.org/10.1371/ journal.pone.0210927

Rowell HC, Bopp RF, Peng F, Velinsky DJ, Bloomfield JA (2015) Annually laminated sediments from Onondaga Lake, New York (USA) provide a basis for high-resolution studies of lake degradation and recovery. J Paleolimnol 53:107-121

Ruuhijärvi J, Malinen T, Kuoppamäki K, Ala-Opas P, Vinni M (2020) Responses of food web to hypolimnetic aeration in Lake Vesijärvi. Hydrobiologia. https://doi.org/10.1007/ s10750-020-04319-6

Renberg I, Hansson H (2008) The HTH sediment corer. J Paleolimnol 40:655-659

Räsänen J, Kauppila T, Salonen VP (2006) Sediment-based investigation of naturally or historically eutrophic lakesimplications for lake management. J Environ Manag 79:253-265

Saarinen T, Wenho H (2005) Minijääsormi sekä muita uusia ja vanhoja ideoita järvisedimentin talvikairaukseen. In: Proceedings of the Congress Abstract Book, Geologian Tutkijapäivät, Turku, pp 72-73

Saarni S (2017) The Sensitivity of annually laminated lake sediments in central and eastern finland to the late holocene climate. Annales Universitatis Turkuensis AII: 331

Salmi P, Malin I, Salonen K (2014) Pumping of epilimnetic water into hypolimnion improves oxygen but not necessarily nutrient conditions in a lake recovering from eutrophication. Inland Waters 4:425-434

Salmi P, Salonen K (2016) Regular buil-up of the spring phytoplankton maximum before ice-break in a boreal lake. Limnol Oceanogr 61:240-253

Salminen S, Saarni S, Tammelin M, Fukumoto Y, Saarinen T (2019) varve distribution reveals spatiotemporal hypolimnetic hypoxia oscillations during the past 200 years in lake lehmilampi. East Finland Quat 2:20. https://doi.org/10. 3390/quat2020020

Salonen K, Sarvala J, Horppila J, Keto J, Malin I, Malinen T, Niemistö J, Ruuhijärvi J (2020) Development of Lake Vesijärvi through four decades of remediation efforts. Hydrobiologia 1-19

Scheffer M, Portielje R, Zambrano L (2003) Fish facilitate wave resuspension of sediment. Limnol Oceanogr 48:1920-1926

Sivarajah B, Rühland K, Labaj AL, Paterson AM, Smol JP (2016) J Paleolimnol 55:357-367

Smith VH (1998) Cultural eutrophication of inland, estuarine and coastal waters. In: Pace ML, Groffman PM (eds) Successes, limitations and frontiers in ecosystem science. Springer, New York, pp 7-49

Smol JP (2009) Pollution of lakes and rivers: a paleoenvironmental perspective. Blackwell publishing, Malden

Spaulding SA, Lubinski DJ, Potapova M, Diatoms of the United States (2008). Available online: http://westerndiatoms. colorado.edu. Accessed on 15 Aug 2020

Tammelin M, Kauppila T, Viitasalo M (2017) Factors controlling recent diatom assemblages across a steep local nutrient 
gradient in central-eastern Finland. Hydrobiologia 799:309-325

Tammelin M, Kauppila T (2018) Quaternary landforms and basin morphology control the natural eutrophy of boreal lakes and their sensitivity to anthropogenic forcing. Front Ecol Evol 6:65. https://doi.org/10.3389/fevo.2018.00065

Tammeorg O, Niemistö J, Horppila J, Haldna M, Kangur K (2013) Sedimentation and resuspension dynamics in Lake Vesijärvi (Finland): comparison of temporal and spatial variations of sediment fluxes in deep and shallow areas. Fundam Appl Limnol 182:297-307

Webb DJ, Robarts RD, Prepas EE (1997) Influence of extended water column mixing during the first 2 years of hypolimnetic oxygenation on the phytoplankton community of Amisk Lake, Alberta. Can J Fish Aquat Sci 54:2133-2145 Westerholm J (2002) Populating Finland. Fennia 180:123-140
Wigdahl-Perry CR, Saros JE, Fritz SC, Hess CT (2017) Investigating potential effects of zooplankton grazing on diatom-inferred drought reconstructions. Hydrobiologia 786:149-165

Zolitschka B, Francus P, Ojala AE, Schimmelmann A (2015) Varves in lake sediments-a review. Quat Sci Rev 117:1-41

Zolitschka B, Enters D (2009) Lacustrine sediments. In: Gornitz $\mathrm{V}$ (ed) Encyclopedia of paleoclimatology and ancient environments. Springer, Dordrecht, pp 485-488

Publisher's Note Springer Nature remains neutral with regard to jurisdictional claims in published maps and institutional affiliations. 